INÖNÜ

SAVAŞLARI'NIN

100. YILI

\title{
Mustafa Kemal Paşa ve İnönü Savaşları ${ }^{1}$
}

\author{
Alaattin UCA ${ }^{2}$
}

\section{Öz}

Kurtuluş Savaşındaki cephelerden biri de Batı Cephesidir. 15 Mayıs 1919'da İzmir'de başlayan Yunan işgaline karşı bu cephede Kuva-yı Milliye birlikleri oluşturularak direniş başlatılmıştır. Kuva-yı Milliye birlikleri bu süreçte önemli başarılar kazanmıştır. Fakat bu birliklerin olumsuzlukları da görülmüştür. Yunan ordusu karşısında kesin zafer kazanmak için düzenli ordu kurulmasına karar verilmiştir. Mustafa Kemal Paşa, Umum Kuva-yı Milliye Kumandanı Ali Fuat Paşa’yı Moskova Büyükelçiliğine görevlendirmiştir. Batı Cephesini ikiye bölmüştür. Cephenin Batı kısmına Albay İsmet Bey’i Güney kısmına da Albay Refet Bey’i atamıştır. Böylece düzenli orduya geçilmiştir. Kuva-yı Milliye birlikleri de düzenli orduya katılmıştır. Fakat bu süreçte bazı sorunlar yaşanmıştır. Ethem ve kuvvetleri, düzenli orduya katılmak istememiştir. Bunlar Yunan ordusuyla iş birliği yapmıştır. Buna rağmen I. İnönü Savaşı kazanılmıştır. İtilaf Devletlerinin davetiyle hem İstanbul Hükümeti hem de Ankara Hükümeti temsilcileri Londra Konferansına katılmıştır. Konferans sonuçsuz kalınca Yunan ordusu yeniden saldırmıştır. Türk ordusunun kahramanca mücadelesi sonunda II. İnönü Savaşı kazanılmıştır. Yunan ordusu bir kez daha geri çekilmek zorunda kalmıştır. Mustafa Kemal Paşa, Batı Cephesinde kazanılan bu zaferlerden memnuniyet duymuştur. Bu çalışmada Mustafa Kemal Paşa'nın İnönü Savaşlaryyla ilgili açıklamaları, düşünce ve yorumları ele alınmıştır.

Anahtar Kelimeler: Mustafa Kemal Paşa, İsmet Paşa, I. İnönü Zaferi, II. İnönü Zaferi

Atıf: Uca, A. (2021). Mustafa Kemal Paşa ve İnönü savaşları. Anadolu Üniversitesi Sosyal Bilimler Dergisi, 21(Özel Sayı), $1-24$.

\footnotetext{
${ }^{1} \mathrm{Bu}$ çalışma etik kurul izin belgesi gerektirmemektedir.

${ }^{2}$ Karamanoğlu Mehmet Bey Üniversitesi Edebiyat Fakültesi Tarih Bölümü, alaattinuca@kmu.edu.tr, ORCID: 0000-0002-4211-6744
} 
iNÖNÜ

SAVAŞLARI'NIN

100. YILI

\title{
Mustafa Kemal Pasha and the Battles of İnönü
}

\author{
Alaattin UCA ${ }^{3}$
}

Submitted by: 22.01 .2021

Accepted by: 23.02 .2021

Article Type: Research Article

\begin{abstract}
One of the fronts in the War of Independence is the Western Front. Against the Greek invasion that started in Izmir on 15 May 1919, Kuva-yl Milliye units were formed on this front and the resistance was initiated. However, the negativities of these unions were also seen. It was decided to establish a regular army in order to win a decisive victory over the Greek army. Mustafa Kemal Pasha assigned Ali Fuat Pasha, the commander of Umum Kuva-yl Milliye, to the Moscow Embassy. It divided the Western Front into two. He appointed Colonel Ismet Bey to the western part of the front and Colonel Refet Bey to the southern part. Thus, the regular army was introduced. The troops of Kuva-yı Milliye also joined the regular army. However, there were some problems during this operation. Ethem and his forces did not want to join the regular army. They cooperated with the Greek army. Despite this, the First Battle of İnönü was won. At the invitation of the Entente States, both the Istanbul Government and the Ankara Government representatives attended the London Conference. When the conference failed, the Greek army attacked again. At the end of the heroic struggle of the Turkish army, the Second Battle of Inönü was won. The Greek army had to retreat once again. Mustafa Kemal Pasha was delighted with these victories on the Western Front. In this study, it is focused on the statements, thoughts and comments of Mustafa Kemal Pasha about the Battles of İnönü.
\end{abstract}

Keywords: Mustafa Kemal Pasha, İsmet Pasha, First İnönü Victory, Second İnönü Victory

\footnotetext{
${ }^{3}$ Karamanoğlu Mehmetbey University Faculty of Letters Department of History, alaattinuca@kmu.edu.tr, ORCID: 0000-0002-4211-6744
} 


\section{Giriş}

İnönü Savaşları Millî Mücadele'de Batı Cephesinde Yunan ordusuna karşı kazanılmıştır. I. İnönü Savaşı 6-11 Ocak 1921, II. İnönü Savaşı ise 23 Mart-1 Nisan 1921 tarihleri arasında gerçekleşmiştir (Türk İstiklâl Harbi, 1966, s. 147, 311, 459).

İzmir’i işgal ederek Anadolu içlerinde ilerleyen Yunanistan 1921 yılı başlarında iç ve dış siyaset bakımından zor duruma düşmüştür. Seçimlerden sonra yeni kurulan Yunan hükümeti, İtilaf Devletlerinin güvenini kazanmak için yeni bir harekâta ihtiyaç duymuştur. Merkezinden uzaklaşan Yunan ordusu Anadolu'da umduğunu bulamamıştır. Bursa-Uşak-Sarayköy hattına kadar ilerlediği halde Türk kuvvetlerini yok edememiş ve siyasi yönden de Türk Millî Hükümetine isteklerini kabul ettirememiştir. Yunan Kralı Konstantin, Yunan Meclisini açarken yaptı̆̆ konuşmada savaşı devam ettireceğine dair söz vermiş ve bu sözünü yerine getirmek zorunda kalmıştır. Bu da Yunan ordusunu zora sokmuştur.

Yunan ordusu ve hükümeti bu durumda iken Anadolu'da Çerkez Ethem ve kardeşlerinin Millî Hükümete karşı ayaklanması kritik bir siyasî ve askerî durum yaratmıştır. Ethem bu durumu Yunanlılara bildirmiş ve bundan istifade ederek taarruz etmeleri hususunda onları teşvik etmiştir. 1921 yılı Ocak ayının başlarında Batı Cephesindeki kuvvetlerin bir kısmının Ethem ile uğraşması Yunanlılara avantaj sağlamıştır. Bu avantajı kullanmak isteyen İstanbul'daki Yunan askeri heyeti de muhtemel gördükleri bir Türk taarruzunu önlemek için kendilerinin taarruza geçmelerini ve Türk ordusunun hazırlıklarını etkisiz kılmayı düşünmüştür. Onlara göre Yunan taarruzu başarıya ulaşırsa Türk kuvvetlerinin yok edilmesi de mümkün olabilecektir. Yunanlılar gerek Batı ve gerekse Güney Cephesi kuvvetlerinin çoğunun Ethem ile uğraştıkları sırada Türk ordusunu yenerek yeni kurulmakta olan Millî Hükümeti yıkabileceklerine inanmıştır. Bu inanış, Yunan ordusunu hazırlıksız ve zamansız bir harekâta sürüklemiştir (Türk İstiklâl Harbi, 1966, s. 150, 151).

6 Ocak 1921'de başlayan Yunan taarruzu sonuçsuz kalmıştır. Türk ordusunun kahramanca mücadelesi sonunda 11 Ocak günü Yunan ordusu eski mevzilerine çekilmiştir. TBMM Hükümetinin kurduğu düzenli ordunun ilk savunma savaşı sonunda kazanılan bu zafer daha sonra kazanılacakların müjdecisi olmuştur. Bu zafer Türk milletinin kendine güvenini artırmıştır. Ethem ayaklanması ve Yunan ileri harekâtı karşısında zor duruma düşen TBMM Hükümeti rahat bir nefes almıştır (Tansel, 1991, s. 22, 25).

İtilaf Devletlerinin daveti üzerine hem İstanbul Hükümeti hem de Ankara Hükümeti temsilcilerinin katılımıyla 21 Şubat-12 Mart 1921 tarihlerinde toplanan Londra Konferansından beklenen sonuç alınamamıştır (Tansel, 1991, s. 39-47).

I. İnönü Savaşında Türk ordusunu yakından tanıyan Yunanlılar bu ordunun zamanla daha çok kuvvetleneceğini anlamış ve bunu engellemek istemişlerdir. Bu nedenle Yunanistan, Anadolu'daki kuvvetlerini artırmıştır. Yunan Hükümeti kazanacakları bir zaferin hem I. İnönü Savaşındaki yenilginin izlerini sileceğini hem de Yunan Kralı’nın prestijini artıracağını düşünmüştür. Ayrıca Sevr Antlaşmasını Türklere kabul ettirmenin de kolaylaşacağını zannetmiştir. Bu nedenle 23 Mart 1921'de Yunan ordusu yeniden saldırıya geçmiştir. Türk ordusunun 31 Mart 1921'de gerçekleştirdiği karşı taarruzla bir defa daha yenilen Yunan ordusu 1 Nisan 1921 günü İnönü ve çevresinden çekilmek zorunda kalmıştır. Böylece II. İnönü Zaferi de kazanılmıştır (Tansel, 1991, s. 78-82). Bu zaferler sonucunda Mustafa Kemal Paşa'nın deyimiyle Türk milletinin makûs talihi yenilmiştir (Apak, 1990, s. 227). 
Mustafa Kemal Paşa bu savaşların Türk ordusunun zaferiyle sonuçlanmasından memnuniyet duymuştur. Bu memnuniyetini de açıkça ifade etmiştir. Yaptığı konuşmalar, söylediği sözler ve gönderdiği tebrik telgraflarıyla bu konudaki düşüncelerini ortaya koymuştur. Bu çalışmada Mustafa Kemal Paşa'nın konuyla ilgili sözleri esas alınarak İnönü Savaşları hakkındaki düşünceleri ve bu savaşlara bakışı ele alınmıştır.

\section{I. İnönü Savaşı}

Mustafa Kemal Paşa'nın I. İnönü Savaşıyla ilgili mütalaaları genelde Ethem ve kardeşlerinin o sırada sergiledikleri davranışlar ve Londra Konferansı ile ilgili gelişmelere yönelik olmuştur. Mustafa Kemal Paşa, I. İnönü Savaşı öncesinde 24 Aralık 1920 günü Batı Cephesi Hareket Şubesi Müdürü Tevfik Bey, Güney Cephesi Kurmay Başkanı Zeki Bey ile İsmet ve Refet Beylere bir telgraf göndererek Gezici Kuvvetlerin (Kuva-yı Seyyare $)^{4}$ Gediz ve Kütahya'da toplanmasının ilgi çekici olduğunu, bunların birinci olarak Karahisar'la (Afyonkarahisar) cephe arasında herhangi bir yerden geçerek Refet Bey'e saldırma ihtimalinin bulunduğunu ifade etmiştir. Buna karşılık gerek 12. Kolorduca ve gerekse Batı Cephesince şimdiden gerekli önlemlerin alınması ve aşırı ölçüde uyanık bulunulması gerektiği hususunda başta İsmet ve Refet Bey olmak üzere ilgilileri uyarmıştır (Onar, 1995, C. 2, s. 224, 225). Ardından 27 Aralık 1920 tarihli telgrafla Gezici Kuvvetlerin, Büyük Millet Meclisi'nin yasaları ve Hükümetin koyduğu kurallara uymak zorunda olduğu hakkında Bakanlar Kurulu Kararı alındığını, fakat bu kuvvetlerin kanun ve kurallara uymak niyetinde olmadıklarının anlaşıldığını, dolayısıyla bu sorunun kuvvet zoruyla çözümlenmesi gerektiğini söylemiştir. Bunun için Meclis'in onayına gerek olmadığını, harekât başarıyla sonuçlandırılırsa Meclis'in yapılan işi onaylayacağını, ellerinde haklı olduklarını kanıtlayacak yeterince delil ve belgenin bulunduğunu ifade ederek Batı Cephesi Komutanı Albay İsmet ve Güney Cephesi Komutanı Albay Refet Bey'e bu kuvvetlerin takip edilmesi, dağıtılmaları için propaganda yapılması ve gerekli tedbirlerin alınması görüşünde olduğunu bildirmiştir (Onar, 1995, C. 2, s. 227). Mustafa Kemal Paşa, 29 Aralık 1920 günü Ethem ve kardeşlerinin birliklerinin başından ayrılarak Hükümete sığınmalarını, bunu yaptıkları takdirde haklarında yasal işlem yapılmayacağını önermiş ve bu önerisi Meclis tarafından kabul edilmiştir (Onar, 1995, C. 2, s. 229). Ancak Ethem ve kardeşleri bu öneriyi de dikkate almamışlardır.

Mustafa Kemal Paşa, I. İnönü Muharebesinin devam ettiği günlerde, TBMM'de 8 Ocak 1921 tarihinde yaptığı konuşmada Birinci Kuva-yı Seyyare Kumandanı Ethem Bey ve kardeşlerinin isyankârane harekâtı hakkında açıklama yaparak, onların teşviki ve verdiği sırlar nedeniyle Yunan ordusunun 6 Ocak 1921'de saldırıya geçtiğini söylemiştir (TBMMZC, 8.1.1337, s. 228). I. İnönü Muharebesinin nasıl başladığını şu sözlerle ifade etmiştir: "Ethem, Tevfik ve Reşit Beyler doğrudan doğruya maiyetlerinde kalan bir kısım kuvvetler ki -en son vaziyetle üç yüz kişi kadar görülmüştür- bunlarla bilâkaydüşart Yunanlıların emrine tabi olmuşlardır. Yunanlılara, şüphe yok ki bunlar birçok esrar ${ }^{5}$ tevdi etmişlerdir. Yalnız bu adamlar bittabi ne ordumuzu bilirler ve ne de ordumuzun celadetini lüzumu kadar takdir edebilirler. Onların esrar diye tevdi ettikleri şeyin hükmi tesiri yoktur. Fakat herhalde mübalağalı bir surette vermiş oldukları malumat ve izahat Yunan ordusunu ve İngilizleri fevkalade heveslendirmiştir. Bunun neticesi olarak iki gün evvel (6 Ocak 1921) Yunan ordusu bütün Garp Cephesinin her noktasında, kendi safları arasında Ethem Bey dâhil olduğu halde, taarruza geçmişlerdir.” (Atatürk’ün Söylev ve Demeçleri, 2006, C. 1, s. 145). Mustafa Kemal Paşa bu sözleriyle I. İnönü Savaşında Yunan ordusunun saldırıya geçmesinde Ethem ve kardeşlerinin etkili olduğunu vurgulamıştır.

\footnotetext{
${ }^{4}$ Kuva-yı Seyyare: Çerkez Ethem’in teşkil ettiği milis kuvvetleri. 
Mustafa Kemal Paşa, 8 Ocak itibariyle düşmana karşı henüz mevcut olan kuvvetlerin tamamının kullanılmadığını, Ethem ve kardeşlerinin faaliyetlerinin memleket ve millet hesabına büyük zayiata ve fırsatların kaybına sebep olduğunu ancak nihai zaferi kendilerinin kazanacağını dile getirmiştir (TBMMZC, 8.1.1337, s. 229).

Mustafa Kemal Paşa bu sözleriyle I. İnönü Muharebesi hakkında hem durum tespiti yapmış hem de gelecekten ümitli olduğunu, orduya ve millete güvendiğini, bu mücadelenin zaferle sonuçlanacağından emin olduğunu göstermiştir.

Mustafa Kemal Paşa'nın yaptığı konuşmanın sonunda Ethem'in ağabeyi Saruhan Mebusu Reşit Bey’in mebusluktan iskatı ${ }^{6}$ Meclis’te aynı gün kabul edilmiştir (TBMMZC, 8.1.1337, s. 228).

10 Ocak 1921 günü Kırşehir Mebusu Yahya Galip Bey, I. İnönü Muharebesi hakkında Meclis'e malumat verilmesine dair şu takriri sunmuştur:

\section{"Riyaseti Celileye}

Bugünün mühim meselesinin harekât-1 harbiyeye dair malumat almaktan ibaret olduğunu anlıyorum. Binaenaleyh her türlü müzakerata tercihan Reis Paşa Hazretlerinin hemen şimdi Meclis'e beyanatta bulunmasını müstaceliyetle ${ }^{7}$ teklif eylerim.

10 Kânunusani 1337/10 Ocak 1921

Kırşehir Mebusu

Yahya Galip" (TBMMZC, 10.1.1337, s. 247).

Kırşehir Mebusu Yahya Galip Bey’in I. İnönü Muharebesi hakkında Meclis'e acil olarak bilgi verilmesi hakkındaki talebi üzerine Mustafa Kemal Paşa söz alarak şunları söylemiştir:

"Müdafaa-i Milliye Vekili Fevzi Paşa Hazretleri maruzatta bulunacaklar. Fakat müstacelen tenevvür ${ }^{8}$ arzu buyurulduğu için hulâsaten vaziyeti söyleyeyim. Malum-u alileri Yunanlılar Bursa Cephesinde iki istikametten taarruza geçmişlerdi. Biri Yenişehir-Köprühisar-Bilecik istikameti, ikincisi İnegöl-Nazifpaşa-Pazarcık-Taraklı ve cenuba ${ }^{9}$ doğru da Gediz'de Ethem kuvveti, Uşak'ta da İslam köy istikametinde yine Yunan kıtaatıdır. Uşak'tan ilerleyen düşman kıtaatı İslam köyünden ileri geçmemişlerdir. Gediz'de 300 kişi ile taarruz eden Ethem püskürtülmüştür. Fakat yine orada bulunan kuvvetlerimizle karşı karşıyadır. Köprühisar mevkiinde düşman tevkif edilmişti. Evvela tart edildi, sonra takviye aldı. Fakat yine binnetice ${ }^{10}$ tevkif edilmişti. Yalnız ilk beyanatımda bulunurken arz etmiştim: Nazifpaşa mevziindeki kuvvetimizi düşman büyük kuvvetlerle ciddi tazyik altında bulundurmaktadır. Bu tazyikin neticesi olmak üzere oradaki kuvvetimiz çekilmek mecburiyetinde kaldı. Oradaki kuvvet denildiği zaman efendim gayet zayıf bir tarassut ${ }^{11}$ kuvveti olduğunu söylemek mecburiyetindeyim. Çünkü malum-u aliniz vaziyet-i askeriyemiz bu isyan münasebetiyle ve düşmanın daha evvel Uşak karşısında bazı tahşidatta ${ }^{12}$ bulunması dolayısıyla merkez-i sıklet ${ }^{13}$ Kütahya havalisine inhisar ${ }^{14}$ etmiştir. Ethem' in o tarafa iltihak ${ }^{15}$ etmesi itibariyle düşman bütün vaziyete vakıf olmuştur. Binaenaleyh Nazifpaşa çiftliğindeki kuvvetin zaafı düşmanca malum idi. Düşman o istikametten Karaköy’e

\footnotetext{
${ }^{6}$ İskat: Düşürülmek.

${ }^{7}$ Müstacel: Acele yapılması gereken.

${ }^{8}$ Tenevvür: Bir şey hakkında bilgi sahibi olma.

${ }^{9}$ Cenub: Güney.

${ }^{10}$ Binnetice: Sonuç olarak.

11 Tarassud: Gözetleme.

${ }^{12}$ Tahşidat: Yığınak.

${ }^{13}$ Merkezi sıklet: Ağırlık merkezi.

${ }^{14}$ İnhisar: Dâhil olma, toplanma.

${ }^{15}$ İltihak: Katılmak.
} 
kadar ilerledi. Tabii bunun şimalinde düşmana karşı kuvvet yetiştirilmeye çalışıldı. Fakat bu kuvvetlerin ancak İnönü'de toplanabileceğini hesap ederek, parça parça kaptırmamak için İnönü'de kuvvetler tahşidine ${ }^{16}$ başlanmıştı. Dün düşman İnönü civarındaki mevzilerimize temas etti. Cepheden taarruz etti. Bu taarruz tevkif edildi. Sonra sol cenaha taarruz edildi, o taarruz da tevkif olundu. Bugün aynı mevazıda ${ }^{17}$ muharebe cereyan etmektedir. Kuvvetlerimiz tamamen İnönü’nün şimalinde ve şarkında imtidad ${ }^{18}$ eden sırtlar üzerindedir. Düşmanın şimdiye kadar inkişaf eden ve doğrudan doğruya muharebeye iştirak eden kuvveti iki fırka kadardır. Bunun gerisinde daha bir Efzun firkas $1^{19}$ tahmin edilmektedir. Binaenaleyh bu dakikada aldığımız son rapora göre bu mevazı üzerinde gayet şiddetli muharebat cereyan etmektedir. Neticesi tabii inkişaf ettikçe Fevzi Paşa Hazretleri izahatta bulunurlar" (TBMMZC, 10.1.1337, s. 247).

Mustafa Kemal Paşa 10 Ocak 1921 günü Meclis’te yaptığı bu konuşmada I. İnönü Savaşının cephedeki seyri konusunda mebusları bilgilendirmiş ve asıl detaylı açılamayı Fevzi Paşa’nın yapacağını bildirmiştir.

Mustafa Kemal Paşa, 11 Ocak 1921 tarihinde Erkân-1 Harbiye-i Umumiye Reisi ${ }^{20}$ ve Garp Cephesi Kumandanı İsmet Bey’e bir telgraf göndermiştir (Atatürk'ün Tamim, Telgraf ve Beyannameleri 4, 2006, s. 384). Bu telgrafın içeriğini de 13 Ocak 1921 günü Meclis'te yaptığ konuşmada açıklamıştır. Mustafa Kemal Paşa Meclis’te I. İnönü Harbi hakkında yaptığı o konuşmada şunları söylemiştir:

"Efendiler! Vaziyet-i harbiyenin safahat-ı muhtelifesi ve suret-i inkişafı hakkında Erkân-ı Harbiye-i Umumiye Reisi ve Müdafaa-i Milliye Vekili ${ }^{21}$ Paşa Hazretleri heyet-i aliyenize daha mufassal malumat arz edecektir. Fakat kendileri henüz harekâtı idare etmekle meşgul olduklarından biraz teehhür ${ }^{22}$ edecektir. Onun için bendeniz, sizce lazım olan ve bu anda bilinmesi mucib-i memnuniyet olabilen hususatı hulasaten arz edeceğim. Malumu alinizdir ki Venizelos'un sükûtiyle ${ }^{23}$ Yunanistan'da bir mesele, bir vaziyet-i mahsusa hâsıl olmuştu. Mevki-i iktidara gelen Konstantin'in takip edeceği siyaset tamamen taayyün ${ }^{24}$ etmemiş gibi idi. Fakat alınan malumata nazaran İngilizler Konstantin'i dahi tazyik ederek kendi emperyalist emellerinin uğrunda baziçe ${ }^{25}$ etmek istiyorlardı. Konstantin krallığını tasdik ettirebilmek için bu hususa mütemayil görünüyordu. Fakat İngilizlere karşı deruhte edeceği vazifeyi ifa etmek için Yunan ordusunu taarruz ettirmek ve bu taarruzunda muvaffak olmak lazım geliyordu. İşte bu sırada idi ki Ethem ve Tevfik ve Reşit hainleri hıyanetlerini fiilen izhar ${ }^{26}$ ederek $^{2}$ Yunan ordusuna iltihak etmiş bulunuyorlardı. Efendiler, Yunan karargâhında ve İngilizlerde bu iltihak ile husule gelen beşaşetin ${ }^{27}$ derecesini takdir etmek için Ethem, Tevfik ve Reşit'in zihniyetlerini biraz izah edeceğim, telakkilerini tefsir edeceğim. Bu bedbahtlarca Garp Ordusunda maddeten ve manen kuvvet olarak yalnız onların tahtı emrinde bulunan insanlar vardı. Esasen ordumuzun kuvve-i maddiyesi bunlardan dun ${ }^{28}$ idi. Öyle farz ediyorlar, öyle zannediyorlardı. Hele maneviyatça ordunun hiç kıymeti yoktu. Ancak düşman karşısında ve harekât mıntıkasında Ethem ve kardeşlerinin kuvveti sayesinde ve bu kuvvetin tesiri altında, bu kuvvetin tedhişiyle durabilirlerdi. Yani Kuva-yı Seyyare ortadan kalkarsa, onların telakkilerine göre hemen ordu ortadan kalkacak idi.

\footnotetext{
${ }^{16}$ Tahşid: Yı̆̆ma.

${ }^{17}$ Mevazı: Mevziler, yerler.

${ }^{18}$ İmtidad: Uzayip gitmek.

${ }^{19}$ Efzun firkası: Yunanistan'ın etek giyen askerlerinden oluşan askeri birlik, tümen.

${ }^{20}$ Erkân-1 Harbiye-i Umumiye Reisi: Genelkurmay Başkanı.

${ }^{21}$ Müdafaa-i Milliye Vekili: Milli Savunma Bakanı.

22 Teehhür: Gecikme.

${ }^{23}$ Bir maymun tarafından ısırılan Yunan Kralı Aleksander'ın ölümünden sonra, Yunan Başbakanı Venizelos'un seçimleri kaybetmesi ve Yunanistan'ı terk etmesi.

${ }^{24}$ Taayyün: Belli olmak, ortaya çıkmak.

${ }^{25}$ Baziçe: Oyuncak, eğlence.

${ }^{26}$ İzhar: Açı̆̆a vurma, belli etme.

${ }^{27}$ Beşaşet: Sevinç, memnuniyet.

${ }^{28}$ Dûn: Zayıf, aşağı.
} 
Yine onların zanlarınca ve zann-1 batıllarınca, milletimizde vahdet ${ }^{29}$ ve tesanüt ${ }^{30}$ yoktu. Milletimizin mümessili yegânesi olan heyet-i aliyenizde de hiçbir vahdet ve katiyet azmi yoktu. Binaenaleyh bütün bu zihniyetleri Yunan karargâhına ve bittabi İngilizlere, İstanbul'a yetiştirmişlerdi.

Şüphe yok ki bundan fazla olarak bütün tertibat-1 askeriyemizi, nerelerde ne kadar askerimiz var, nelerimiz mevcut, vesaitimiz ne derecededir, hangi yerlerden ne kadar zamanda ne kadar kuvvet getirebiliriz, bittabi bunları da söylemişlerdir. İşte Konstantin'in bundan fevkalade cüret alarak seri bir hareketle zayıf olduğu kendilerince tayin edilen istikametten yürüyerek Eskişehir'i işgal ederek ona göre harekât-1 sairesini tertip etmek istemiş olduğu tahakkuk etti. Şüphe yoktur ki bu harekete Ethem kendi kuvvetleriyle dahi bilfiil iştirak etti.

Ethem ve kardeşlerinin kuvveti, henüz kuvvetlerimiz Gediz civarında bulunurken bir darbe ile dağıtıldı. Malum-u aliniz onu müteakip kıtaat-1 askeriyemiz asıl tehlikenin gelmekte olduğu istikamete tevcih ${ }^{31}$ edildi. $^{2}$ $\mathrm{O}$ istikamette yani Kütahya havalisinde bazı şeyleri söylemekte beis görmeyeceğim.

Orada 600-800 kişiden ibaret ufak bir kuvvet Ethem'i dağıttıktan sonra yalnız üç yüz kişi beraberinde kalmıştı. Yanında bir bataryayı beraber götürmüş fakat o bataryanın zabiti kaçmıştı. Batarya istimal ${ }^{32}$ edilemeyecek bir halde bulunuyordu. Bu kuvvetlerin buradan çekilip gittiğini görünce yine birtakım insanları başına toplamış altı yüz kişiye belki sekiz yüz kişiye çıkarmış. Bataryaya da ihtimal Yunanlılardan gönderilen topçularla bir faaliyet vermiş ve evvelki günden beri Kütahya'da bulunan ufak kuvvetimize tasalluta ${ }^{33}$ başlamıştır. Binaenaleyh evvelki gün, dün ve bugün orada bulunan bu cüzi kuvveti, bu aciz kuvveti mütemadiyen darbelerle meşgul etmiştir. Hatta şimdi gelen bir raporda 'Sağ cenahta Aydoğdu sırtları istikametine ricat eden usat ${ }^{34}$ takip olunmaktadır' deniliyor. Efendim, işte bu ufacık kuvvet mağlup etmeye kâfi gelebilir. Fakat bittabi vaziyeti daha ciddi mütalaa ettik ve bulaşık insanları biran evvel tathir ${ }^{35}$ edebilmek için oraya süvari ve piyade olmak üzere bugün faik ${ }^{36}$ kuvvet sevk olunmuştur. İntizar ${ }^{37}$ ediyorum. Bu faik kuvvet bunu büsbütün perişan edecektir. Şimdi Fevzi Paşa Hazretleri haber göndermişler, geleceklerdir. Onun için daha çok muhtasar ${ }^{38}$ geçeceğim.”

Ethem ve kardeşlerinin I. İnönü Muharebesi sırasında sergiledikleri davranışların içeride ve dışarıda meydana getirdiği etkileri bu şekilde ifade eden Mustafa Kemal Paşa konuşmasına şöyle devam etmiştir:

“Asıl İnönü Meydan Muharebesine intikal ediyorum: Malum-u aliniz kuvvetlerimizi İnönü havalisinde toplamaya başladık, düşman oraya kadar geldi. Fakat Nazifpaşa mevkiinde ve sonra Pazarcık mevkiinde daima bir taburdan ibaret (TBMMZC, 13.1.1337, s. 278) olan gayet küçük kuvvetler bütün bu düşman ordusuna iki üç gün kadar zayi ettirdi. Düşmana nazaran az olan kuvvetlerimiz İnönü’de toplanmıştı. Burada vuku bulan meydan muharebesinde düşman zayiat-ı azime ile mağlubiyeti his ve idrak etti ve seri bir suretle ricata başladı. Kuvvetlerimiz malum-u aliniz Otalbali, Beşkardeş tepeleri hattında bulunuyordu. Dün tekmil ${ }^{39}$ ordu düşmanı takiben ileriye doğru hareket etti ve dün akşam aldıkları vaziyet 20-30 kilometre kadar daha ileride olmak üzere Gündüzbey, Metris, Akpınar, Karaağaç hattına kadar ilerledi ki bu hat piyade kısm-ı küllilerinin hattıdır. Fakat

\footnotetext{
${ }^{29}$ Vahdet: Birlik.

${ }^{30}$ Tesanüt: Beraberlik, uyum.

${ }^{31}$ Tevcih: Döndürmek, yöneltmek.

${ }^{32}$ İstimal: Kullanmak, faydalanmak.

${ }^{33}$ Tasallut: Saldırmak, rahatsız etmek.

${ }^{34}$ Usat: Asiler.

${ }^{35}$ Tathir: Temizlemek.

${ }^{36}$ Faik: Güzide, üstün.

${ }^{37}$ İntizar: Ümitle beklemek.

${ }^{38}$ Muhtasar: Kisa.

${ }^{39}$ Tekmil: Bütün, tam.
} 
süvari kolları daha ileri gitmiştir. Bir kısım Bozüyük bir kısmı da Mezit vadisine doğru ve daha ileri de Söğüt ve Pazarcık istikametinde keşif kıtaatı sevk edilmiştir. Bugün ordu kumandanlığından gelen bir raporda düşmanın iki alay piyade iki bölük süvari ve bir batarya toptan ibaret kuvvetinin Söğüt, Bilecik, Yenişehir istikametinde ricat etmekte olduğu bildiriliyor ve kuva-yı asliyesinin de Pazarcık, Nazifpaşa, İnegöl, Bursa istikametine doğru çekildiği bildiriliyor. Düşman gayet seri bir ricat yapıyor. Birçok eşya ve malzeme terk ederek çekiliyor. Yalnız güzergâhlarında ahali-yi İslamiyeye tecavüz ve zulüm ikaından ${ }^{40}$ geri durmuyorlar. Buna mukabil ordu kumandanı doğrudan doğruya Mezit vadisinden düşmanın hatt-ı ricatını kesmek üzere mühimce bir süvari kuvveti sevk ediyor. Şimalde de piyade ve süvari kuvvetinden mürekkep bir kuvvet doğrudan doğruya Yenişehir istikametine doğru düşmanın hatt-1 ricatını kesmek emrini almış bulunuyor. Şimdi bunun netayicine ${ }^{41}$ intizar edeceğiz. Efendim, Meclis-i Aliniz hal-i içtimada bulunmadığı için, bu muzafferiyetin hakikaten pek mühim ve kıymettar olan vaziyet-i siyasiye ve askeriyemiz ve ahval-i dâhiliyemiz üzerindeki tesirinin derece-i ehemmiyetini takdir buyuracağınıza emin olarak, İnönü Meydan Muharebesini kazanmış olduğundan dolayı Garp Ordusu Kumandanı ve tekmil zabitan ve kumandan ve efradını heyeti aliyeniz namına tebrik etmiştim.”

Mustafa Kemal Paşa, konuşmasının bu bölümünde Batı Cephesinde kazanılan I. İnönü Zaferi nedeniyle Batı Cephesi Kumandanı İsmet Bey'e gönderdiği şu tebrik telgrafını da mebuslarla paylaşmıştır:

\section{Erkân-ı Harbiye-i Umumiye Reisi ve Garp Cephesi Kumandanı İsmet Beyefendi}

İnönü Meydan Muharebesinde, Garp Cephesi kıtaatının yümünl ̈̈² ve kahir kumandanız altında ihraz $z^{43}$ eyledikleri galebe-i katiyeden dolayı zat-ı devletlerine ve kahraman ordunuzun bilumum kumandanlarıla zabitan ve efradına Büyük Millet Meclisi'nin kalbi tebrikatın takdim ve bu muvaffakiyetin mukaddes topraklarımızı düşman istilasından kâmilen tahlis edecek olan zafer-i katiye bir mukaddeme-i hayır olmasını eltaf-ı ilahiyeden tazarru ${ }^{44}$ eder ve işbu tebrikatın umum Garp Ordusu efrat ve zabitanına iblağını ${ }^{45}$ rica ederim.

\section{B. M. Meclisi Reisi}

\section{Mustafa Kemal}

Mustafa Kemal Paşa bu açıklamayı yaparken Bolu Mebusu Tunalı Hilmi Bey araya girerek İsmet Bey’in, kumandanların ve icap edenlerin birer derece terfilerini teklif etmiştir.

Bunun üzerine Mustafa Kemal Paşa, konuşmasına şöyle devam etmiştir:

"Müsaade buyurur musunuz? Bu mesele hakkında daha biraz vaziyeti umumiye tespit edilsin ve ihraz edilmiş olan bu meydan muharebesi muzafferiyetini tetvic ${ }^{46}$ edecek intizar ettiğimiz birkaç şey vardır. Ondan sonra yine tensip buyurursanız buyurduğunuz şey yapılır.”

Mustafa Kemal Paşa I. İnönü Muharebesinin kazanılmasından sonra 13 Ocak 1921 tarihinde Meclis’te yaptığ1 bu konuşmada savaşın sebepleri, seyri ve kazanılmasıyla ilgili görüşlerini belirtip İsmet Paşa'ya gönderdiği telgraftan bahsettikten sonra İsmet Bey'in kendisine gönderdiği şu telgrafı da Meclis kürsüsünden okumuştur:

\footnotetext{
${ }^{40}$ İka: Fena bir şey yapmak, vuku buldurmak.

${ }^{41}$ Netayic: Neticeler, sonuçlar.

${ }^{42}$ Yümn: Kuvvetli, uğurlu, bereketli.

${ }^{43}$ İhraz: Nail olmak, erişmek, kazanmak.

${ }^{44}$ Tazarru: Yalvarmak.

${ }^{45}$ İblağ: Eriştirme, gönderme.

${ }^{46}$ Tetvic: Taç giydirme.
} 


\section{B. M. Meclisi Reisi Mustafa Kemal Paşa Hazretlerine}

Avn-i Hakkla İnönü Meydan Muharebesinin kazanılmasından dolayı Büyük Millet Meclisi'nin kalbi tebrikat ve temenniyatı ordunun bütün efrat ve zabitanını, fahr-u şükrana müstağrak ${ }^{47}$ kılmıştır. Mukadderatımızı istiklali mutlak ile deruhte etmiş olan Büyük Millet Meclisi'ne bilakaydüşart irtibat ve inkıyattan ${ }^{48}$ aldiğı feyz-i manevi ve kutsi ile mukaddes topraklarımızın istihlas ${ }^{49}$ vazifesini ifa edeceğine ordunun kanaat-i katiye ile mutmain bulunduğunu zat-ı riyasetpenahilerine arz ve temin eylerim.

\section{I.1337}

\section{Erkân-ı Harbiye-i Umumiye Reisi ve}

Garp Cephesi Kumandanı

Ísmet

Mustafa Kemal Paşa, Meclis’te yaptığı konuşmasına devam ederek şunları söylemiştir:

Efendiler, bendeniz bu meyanda heyet-i aliyenize suret-i mahsusada teşekküratımı arz etmek istiyorum. Sebebini izah edeceğim. Aleyhimize cereyan eden harekâtın hakikaten birçok kalpleri endişeye duçar edecek mahiyette olduğunu itiraf etmek lazımdır. Böyle bir manzara karşısında Meclis-i Aliniz fevkalade bir sükûnet, itidal-i dem ${ }^{50}$ ve azim göstermiştir. Hükümete, kumandanlara, orduya karşı emniyet ve itimadını hüsn-ü muhafaza etmiş ve neticeye kemal-i sükûnetle intizar etmiştir. Meclis-i Alinizde tezahür eden bu hal-i ulvi emin olunuz hepimize ve bütün millete aynı suretle hüsn-ü tesirini yapmıştır. Eskişehir'den gelen birçok zevata bizzat sorabilirsiniz. Daima buradaki sükûnet oraya sükûnetbahş olmuştur. Hâlbuki düşman Eskişehir'e iki, üç saat mesafeye kadar gelmişti. Eğer Meclis’te ufak bir telaş olsaydı bu, bütün memlekete sirayet edebilirdi. Hatta orduya sirayet edebilirdi ve maazallah arzu edilmeyen (TBMMZC, 13.1.1337, s. 279) netayic karşısında kalınabilirdi. İşte heyet-i celilenizin sükûnet ve metanetinin tesir ve neticesi olmak üzere İnönü Meydan Muharebesi kazanılmıştır. Bundan dolayı teşekküratımı arz eylerim. Efendim, Fevzi Paşa Hazretleri geldikleri vakit daha fazla malumat vereceklerdir. Bu kadarla iktifa ediyorum (TBMMZC, 13.1.1337, s. 280).

Mustafa Kemal Paşa bu sözleriyle I. İnönü Zaferinin kazanılmasında Meclis’in dirayeti ve soğukkanlılığının etkili olduğunu ve Meclis’teki mebusların bu metanetinin ordu ve halka da örnek teşkil ettiğini vurgulamıştır. Aynı gün Mustafa Kemal Paşa Büyük Millet Meclisi'nde ikinci celsede Fevzi Paşa'nın I. İnönü Meydan Muharebesiyle ilgili bilgi verdiği oturumda yapılan konuşmalar sırasında Bursa Mebusu Muhittin Baha Bey’in ifadelerinden etkilenerek söz alıp şunları söylemiştir:

Arkadaşlar Muhittin Bey’in gayet kıymetli sözlerinin hâsıl ettiği hissiyata tercüman olmak üzere bir iki kelime arz edeceğim. Milletimiz bugün bütün mazisinde olduğundan daha çok ve ecdadından daha çok ümit vardır. Bunu ifade için şunu arz ediyorum. Kendilerinin tabiri veçhile cennetten vatanımıza nigehban ${ }^{51}$ olan Merhum Kemal demiştir ki:

Vatanın bağrına düşman dayadı hançerini

Yok mudur kurtaracak bahtı kara maderini.

\footnotetext{
${ }^{47}$ Müstağrak: Batmış, gark olmuş.

${ }^{48}$ İnkıyad: İtaat etme, bağlı kalma.

${ }^{49}$ İstihlas: Kurtarma.

${ }^{50}$ İtidali dem: Soğukkanlı davranış.

${ }^{51}$ Nigehban: Gözcü, gözetici, bekçi.
} 
İşte ben bu kürsüden bu Meclis-i Alinin Reisi sıfatıyla, heyet-i aliyenizi teşkil eden bütün azanın her biri namına ve bütün millet namına diyorum ki:

Vatanın bağrına düşman dayasın hançerini

Bulunur kurtaracak bahtı kara maderini (TBMMZC, 13.1.1337, s. 285).

Mustafa Kemal Paşa tarihe geçen bu sözleri 13 Ocak 1921 günü I. İnönü Zaferinden kısa bir süre sonra Meclis’te bu zaferle ilgili görüşmeler yapılırken söylemiştir.

20 Ocak 1921 günü de Mustafa Kemal Paşa, TBMM'de yaptığı konuşmada I. İnönü Muharebesinden sonra Türk ordusunun Yunan ordusunu takip edecek ve hatta Bursa'ya girecek kuvvetinin olduğunu ancak bazı sebeplerden dolayı buna karar vermediklerini ve bunun için durduklarını ifade etmiştir. Mustafa Kemal Paşa bu konuda şunları söylemiştir: "Erkân-1 Harbiye-i Umumiyemiz cidden nihayetine kadar takip etmek ve Bursa’ya girmek kararını vermiş olsa idi kuvveti ona müsait idi. Takipten sarf-1 nazar ${ }^{52}$ eden kuvvetler esasen

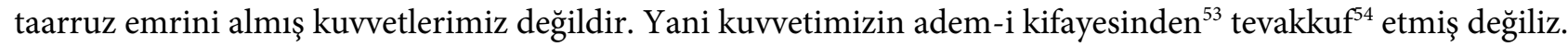
Karar vermemiş olduğumuzdan dolayı tevakkuf ettik ve zannediyorum ki bunun bazı esbap ve mülahazatını da bir münasebetle arz etmiştim (Atatürk'ün Söylev ve Demeçleri, 2006, C. 1, s. 158).

Mustafa Kemal Paşa, 1 Mart 1921 günü Meclis'in ikinci içtima senesinin açılış konuşmasında doğuda Ermenilere karşı kazanılan başarıyı ve batıda Yunanlılara karşı kazanılan I. İnönü Zaferini kastederek şunları söylemiştir: "Bugün her cephede muzafferane harp eden ve vatan müdafaasının ne demek olduğunu tamamen müdrik ordularımız vardır. Bu ordular sayesinde Şarkta Ermenistan muzafferiyetini kazandık ve Garpta Yunanlıları mağlup ettik" (TBMMZC, 1.3.1337, s. 3).

1 Mart 1921 günü Garp Cephesi Komutanı İsmet Paşa da Meclis'e gelerek ikinci celsede bir konuşma yapmıştır. İsmet Paşa konuşmadan önce Hakkâri Mebusu Mazhar Müfit Bey, İnönü kahramanlarının kahraman kumandanı İsmet Paşa'ya Meclis adına teşekkür etmek istediğini ve kendisine Meclis adına yetki verilmesini istemiştir. O oturumda Meclis Reisliği koltuğunda oturan Mustafa Kemal Paşa: "Müsaade buyurun. Efendim, Mazhar Müfit Beyefendi'yi, Garp Ordusu Kumandanı İsmet Paşa Hazretlerine, Meclis tarafından beyan-1 teşekküre memur buyuruyor musunuz?” diye sormuştur. Meclis’ten: Hay hay, maaliftihar sesleri yükselmiştir. Bunun üzerine Mazhar Müfit Bey, ardından da İsmet Paşa Meclis'e hitaben konuşmuştur. Aynı oturumda Antalya Mebusu Hamdullah Suphi Bey ilk defa İstiklal Marşını Meclis’te okumuştur (TBMMZC, 1.3.1337, s. $7,8,13,14)$.

Mustafa Kemal Paşa, I. İnönü Zaferinin yıldönümü dolayısıyla Hâkimiyet-i Milliye gazetesine verdiği 10 Ocak 1924 tarihli demeçte şunları söylemiştir: "I. İnönü Muharebesi 6 Kânunusani ${ }^{55} 337$ / 1921günkü vaziyet üzerinden mütalâa olunmalıdır. O gün, Garp Cephesi kuva-yı asliyesi Gediz ve şarkında toplanmış bulunuyordu. Bu kuvvet yeni Türkiye Devletinin tesisine ve Millet Meclisi'nin mevcudiyet ve meşruiyetine isyan eden hain kuvvetleri tenkil ${ }^{56}$ vazifesini almıştı. Bursa istikamet-i umumiyesine karşı Bilecik-Pazarcık hattında zaif bir fırka terkedilmişti. Uşak-Afyon istikametinin temini için de müctemi ${ }^{57}$ kuva-yı asliyenin tesiri kâfi görülmüștü. Ankara'da henüz hal-i teşekkülde yalnız bir fırka vardı. Yunan ordusunun mühim kuvvetler ile Bursa'da ve Uşak'ta bulunduğu malûm idi. Asi kuvvetler kısm-i küllisi ile Simav'da ve bir kısım kuvvetleri

\footnotetext{
${ }^{52}$ Sarf-1 nazar: Vazgeçme, cayma, dikkate almama.

${ }^{53}$ Ademi kifaye: Yetersizlik.

${ }^{54}$ Tevakkuf: Durmak, duraklamak.

${ }^{55}$ Kânunisani: Ocak ayı.

${ }^{56}$ Tenkil: Sindirmek, etkisiz kılmak, cezalandırmak.

${ }^{57}$ Müctemi: Topluca, hepsi.
} 
Emet'te toplanmış duruyordu. İşte bu vaziyet içinde bulunduğumuz gün, düşman ordusunun mühim faaliyetinden haberdar olduk. Filhakika, üç kuvvetli düşman firkası, Bursa'da İnegöl ve Yenişehir yollarıyla yürüyüşe girdi. Bu istikametteki münferit fırkamıza temas etti. Uşak-Dumlupınar yolundan da iki düşman fırkası harekete başladı. Kânunusaninin altıncı günü öğleden sonra şu karar verildi: Gediz'den bir fırka ve Ankara'daki fırka İnönü mevziinde tahşid edilecek Bilecik-Pazarcık hattındaki münferit fırka mezkûr mevazıa kadar çekilerek orada toplanacak olan firkalar ile birleşecek, Bursa'dan ilerleyen düşman kuvvetleriyle İnönü mevazınnda katî muharebe kabul olunacak, Gediz'de bırakılacak olan yalnız bir fırka Kütahya'ya kadar çekilerek Bilecik, Dumlupınar mevazınndan gelmiş olan kuvvetler tekrar oraya avdet edecek ve Afyonkarahisar istikametini müdafaa edecek. Zaten Garp Cephesi kuva-yı umumiyesi de bundan ibaretti. Bu planın tatbikine 7 Kânunusaniden itibaren başlandı. 8 Kânunusani günü tarafeyn kuvvetleri İnönü mevzilerinde muharebe temasına geldi. Dokuzuncu ve onuncu günlerde İnönü mevazını ihtiva eden Gündüzbey, Kavalca hattı umumisinde kanlı ve buhranlı safhalar oldu. Meydan muharebesi tarafeyn kuvvetlerinin müteakiben yetişmesiyle bir tesadüfi meydan muharebesi şeklinde inkişaf etti. Dokuzuncu günü yalnız sol cenahta vuku bulan ciddi muharebeler onuncu günü bütün cephe boyunca ve bütün şiddetiyle cereyan etti.

Hayat ve istiklâl gayemiz istila ve tecavüz hırsiyle çarpışıyordu. Nihayet ayın on birinci günü sabahı muharebe meydanı meşru gayenin muzafferiyet fecrine ${ }^{58}$ bir saha-i tecelli ${ }^{59}$ oldu. Yeni Türkiye Devletinin küçük fakat milli mefkûreli genç ordusu, en dar bir hesapla üç misli düşmanı İnönü Meydan Muharebesinde mağlup etti. Sevkulceys $\varsigma^{60}$ sanatının en nazik icabatını isabetle tatbik etti. Hutut-u dâhile istimalinde ${ }^{61}$ tarih-i harbe parlak bir misal yazdi.

Yeni Türkiye Devletinin hâris-i istiklâli, ${ }^{62}$ mütevazı bir mevcudiyet içinde gayr-i kabil-i itfa ${ }^{63}$ bir ateşin imha edici alevleriyle kendini ve yeni devletin bünyesindeki resanet-i ${ }^{64}$ ulviyeyi I. İnönü Meydan Muharebesinde cihana ispat etti” (Atatürk'ün Söylev ve Demeçleri, 2006, C. 3, s. 95-96).

TBMM'de yaptığı konuşmalar ve basına verdiği demeçlerle I. İnönü Savaşı hakkında düşüncelerini dile getiren Mustafa Kemal Paşa, Nutuk'ta da bu konuya yer vermiştir. Mustafa Kemal Paşa'nın burada verdiği izahata göre, Ethem kuvvetlerinin peşine düşen birliklerimiz 5 Ocak 1921 günü Gediz’i işgal ederek, o civarda toplanmıştır. Ethem ve kardeşleri de kuvvetleri ile birlikte düşman saflarında yerlerini almıştır. Artık Ethem olayı diye bir şey kalmamıştır. Türk ordusunun içinde bulunan düşman kovularak kendi cephesine gönderilmiştir.

Bundan sonra yalnız bir tek düşman cephesi ve bu cephe ile ilgili olaylar kalmıştır. Bir gün sonra, 6 Ocak 1921'de Yunan ordusunun tamamı bütün cephe üzerinde her noktadan taarruza geçmiştir.

İznik’ten, Gediz üzerinden Uşak’a kadar çekilen hattın, Gediz’in kuzeyinde kalan parçası iki yüz kilometredir. Gediz'den Uşak'a olan parçası da otuz kilometre kadardır (Atatürk, 1994, s. 372). Düşman, üç tümenle bu hattın kuzey ucundan Eskişehir üzerine yürümüştür. Gediz'de bulunan önemli kuvvetlerimiz, Eskişehir üzerinden bu düşman tümenlerini karşılamaya mecbur kalmış, karşılamış ve yenmiştir. İnkılabımızın tarihine, I. İnönü Zaferi'ni kaydetmiştir.

\footnotetext{
${ }^{58}$ Fecr: Tan yerinin ağarması, şafak vakti, sabah.

${ }^{59}$ Tecelli: Kader, talih.

${ }^{60}$ Sevkulceyş: Askeri birliklerin sevk ve idare edilmesi.

${ }^{61}$ İstimal: Kullanma.

${ }^{62}$ Hâris-i istiklâl: Bağımsızlığın bekçisi, koruyucusu.

${ }^{63}$ Gayr-i kabil-i itfa: Söndürülmesi mümkün olmayan.

${ }^{64}$ Resane: Hasret, arzu.
} 
Güney Cephesi'ne ait olan kuvvetler, eski yerlerine Dumlupınar'a iade edilmiştir. Kütahya'da yalnız 61'inci Tümen, iki alay kadar kuvvetiyle İzzettin Bey (Ordu Müfettişi İzzettin Paşa) komutasında bırakılmıştır.

Mustafa Kemal Paşa Meclis'in açık oturumunda Ethem ve kardeşlerinin bu savaş sırasındaki durumunu anlatmış, herkes gerçeği görmüş ve anlamıştır. Ethem ve kardeşlerinin lehinde ve yumuşak hareket edilmesi görüşünde olanlar, bu defa aleyhlerinde ve pek coşkun hale gelmiştir. Mustafa Kemal Paşa 8 Ocak 1921 günü Meclis'te konuşurken "Ethem, Tevfik ve Reşit Beylerin” demesi üzerine konuşmasına itiraz edilmiştir. Yükselen bir ses: "Paşa Hazretleri, artık "Bey" demeyiniz, "Hain” deyiniz uyarısında bulunmuştur. Mustafa Kemal Paşa ise "Ethem ve Tevfik hainleri diyeceğim, fakat daha Büyük Millet Meclisi üyesi sıfatını taşıyan Reşit Bey için de aynı sözü kullanmak mecburiyetindeyim. Yüce heyetinize olan saygım dolayısıyla bunu söyleyemem. Önce Reşit Bey’in Büyük Millet Meclisi üyeliğinin kaldırılmasına oy vermenizi rica ederim” demiştir.

Başkan, "Millet ve memleketin yüksek çıarları aleyhine silah kullanarak düşmanlarla iş birliği yapan Manisa Milletvekili Reşit Bey’in milletvekilliğinin kaldırılmasını kabul buyuranlar el kaldırsın!” demiş. Eller kalkmış ve kabul olunmuştur.

Yunan ordusunun giriştiği bu taarruzda Ethem ve kardeşleri de kendilerine düşen görevi yerine getirmekten geri durmamıştır. Tekrar Kütahya’ya yönelerek, orada bulunan zayıf tümenimize saldırmaya başlamıştır. İzzettin Paşa'nın sağlam karakteri, vukuflu komutası ve emrindeki Türk subay ve erlerinin yüksek kahramanlıkları Ethem ve kardeşleriyle saldıran hain kuvvetleri yenerek geri çekilmeye mecbur etmiştir. Eğer kendi şahısları da dahil olmak üzere toptan yok edilmekten kurtulabilmişler ise bunu da hiç sevmedikleri Refet Paşa'ya borçludurlar.

Refet Paşa, iki süvari tümeniyle, Dumlupınar'ın on kilometre kadar doğusunda Küçükköy'de bulunmuştur. Kütahya'daki 61'inci Tümene batıdan taarruz eden Ethem kuvvetlerini derhal yenmek ve yok etmek üzere hareket emri verilmiştir. Refet Paşa'nın kendi süvarileriyle Ethem kuvvetlerinin yan ve arkasına gitmesi önerilmiştir (Atatürk, 1994, s. 373). Bulunduğu yerden kuzeye, Kütahya’ya bakılacak olursa, bu görevin tabii bir yürüyüşle ve pek etkili bir şekilde yapılabileceği mümkün görülmüştür. Hâlbuki Refet Paşa, gereken yere gitmemiş. Bunun aksi tarafına, Kütahya’nın batısına değil, doğusuna Alayunt’a gitmiş. Süvari kuvvetleri, 12 Ocak 1921 günü öğleye doğru Alayunt bölgesine ulaşmıştır.

Refet Paşa, İzzettin Paşa ile görüşmek üzere Kütahya’ya gitmiştir. İzzettin Paşa, süvari tümenlerinin Kütahya güneyinden, Yellice dağı batısından, tamamen süvariden ibaret olan Ethem kuvvetlerinin gerilerine gönderilmesini teklif etmiştir.

Refet Paşa, iki tarafın savaş durumu hakkında tam bir bilgisi olmadığını ileri sürerek, böyle bir harekete yanaşmamıştır. Refet Paşa, İzzettin Paşa kuvvetleri, doğuya, Porsuk suyu gerisine çekilme durumu ile karşılaşırsa, süvarileriyle Kütahya ovasından asilerin yan ve gerilerine taarruzu düşünmüştür. Atlı asilerin hayvanlarından inip piyade tümenimiz karşısında yaya olarak savaştığı en zayıf durumunda bile üzerine yürümekte kararsızlığa düşen komutanın, piyade tümenimiz yenilmiş olarak geri çekilirken atları üzerinde bulunacak, manevi güçleri yükselmiş asilerin, hangi yanına ve nasıl taarruz etmeyi düşündügüu, gerçekten her asker için üzerinde durup düşünülecek bir mesele olmuştur. 
Savaş alanına, top ve tüfek sesine gelen kuvvetin, bir tek tüfek atmadan, savaşmakta olan kendinden bir kuvvetin yenilmesini beklemesi ve ondan sonra iş görebileceğini sanması, yalnız asker olanların değil, en sade görüşlü insanların bile akla yatkın bulacağı bir düşünce olarak görülmemiştir. Görev ve fedakârlık, savaşan birliklerin yenilmeden, çekilmeden başarısını sağlamaya çalışmakla yerine getirilir.

Arkadaşı savaşırken ve yardıma muhtaç iken, seyirci kalmış olan komutanlar, arkadaşının yenilgisine şahit olabilirlerse de tarihin amansız tenkit ve suçlamalarından asla kurtulamazlar.

İzzet Paşa, 11 Ocak 1921 öğlesinden 13 Ocak gece yarısına kadar devam eden şiddetli ve kritik çarpışmalar sırasında, süvari gruplarının da taarruza katılması zamanının geldiğini Genelkurmay Başkanlığına bildirmiştir. Refet Paşa, Güney Cephesi'nden getirtmekte olduğu 8'inci Tümen yetiştiği takdirde, 14 Ocak'ta taarruza geçmek niyetinde olduğunu, birliklerine duyurmuştur. İzzettin Paşa, 11, 12, 13 Ocak günlerinde yalnız başına düşmanla savaştıktan sonra, akşam gün batarken yaptığı bir karşı taarruzla asileri yenerek kaçmaya mecbur etmiştir (Atatürk, 1994, s. 374). Refet Paşa, muharebeye seyirci kalmak suretiyle büyük bir fırsatı kaçırmıştır. Ethem ve kuvvetlerinin geri çekilmesine elverişli bir durum yaratmıştır. 14'üncü günü emri altında bulunan bütün süvari kuvvetlerini Süvari Tümen Komutanlarından Derviş Bey’in (Kolordu Komutanı Derviş Paşa) emrine vererek, onu Ethem'in takibi ile görevlendirmiştir. Derviş Paşa, Afşar'da özellikle Gediz'de Ethem kuvvetlerinin gerilerine doğru, geceleri de yürümek suretiyle indirdiği korkunç darbelerle Ethem, Tevfik ve Reşit kardeşleri sersem etmiştir. Kuvvetlerinin toplanmasına zaman bırakmamıştır. Derviş Bey, Ethem ve kardeşlerini 14 Ocak'tan 22 Ocak'a kadar dokuz gün nefes aldırmaksızın durmadan takip etmiştir. Sonunda bütün Ethem kuvvetleri esir edilmiş; yalnız Ethem, Tevfik ve Reşit kardeşler yine bir görev almak üzere düşman ordugâhına kaçabilmiştir.

Asi Ethem ve kardeşlerinin kuvvetleri ortadan kaldırılmıştır. Yunanlılar İnönü'de üç günde yenilmiştir. Büyük Millet Meclisi’nin ferahlayacağı ve memnun olacağı yeni bir devir açılmıştır (Atatürk, 1994, s. 375).

Gerek Meclis’te ve Meclis dışında yaptığı konuşmalarda ve gerekse Nutuk’ta I. İnönü Zaferiyle ilgili açıklamalar yapan Mustafa Kemal Paşa, I. İnönü Muharebesinin neticesine önem vermiştir. Bu savaşın kazanılmasından memnun olmuştur. Bu muharebeden kârlı çıkıldığını kabul etmiştir. Batı Cephesinde kazanılan bu ilk askeri başarı hem ordu hem de Mustafa Kemal Paşa üzerinde olumlu tesir yapmıştır (İnönü, 1985, s. 243-245).

\section{II. İnönü Savaşı}

Yunan ordusunun 23 Mart 1921 günü II. İnönü Muharebesi kapsamında Batı Cephesinde yeniden saldırıya geçtiği, ertesi gün Erkân-1 Harbiye-i Umumiye Reisi ve Müdafaa-i Milliye Vekili Fevzi Paşa tarafından Meclis'te yapılan bir konuşma ile duyurulmuştur (TBMMZC, 24.3.1337, s. 229-230). Fevzi Paşa, 2 Nisan 1921 günü de yine Meclis'te yaptığı konuşmada bu muharebenin de İnönü mevzilerinde vuku bulduğunu, yedi gün, yedi gece devam eden muharebelerde düşmanın yenilerek defedildiğini söylemiştir (TBMMZC, 2.4.1337, s. 322). Fevzi Paşa, bu zaferin kazanılmasından dolayı Meclis'in takdirlerini İsmet Paşa'ya bildirmiş, İsmet Paşa da Fevzi Paşa'nın şahsında Meclis'e teşekkürlerini sunmuştur (TBMMZC, 4.4.1337, s. 369). Fevzi Paşa, 13 Nisan 1921 günü Meclis’te bir konuşma daha yaparak II. İnönü Zaferinden sonra devam eden harbin ikinci safhası hakkında bilgi vermiştir (TBMMZC, 13.4.1337, s. 474-475).

Mustafa Kemal Paşa, 28-29 Mart 1921 gecesi Batı Cephesi Komutanı İsmet Bey’e bir telgraf göndererek Millet Meclisi Muhafız Taburunu yarın öğleye cepheye yetiştirilecek olan öteki kuvvetlerle birlikte İsmet Bey’in emrine girmek üzere, gece saat 12'de cepheye gönderdiklerini dile getirmiştir. Bu taburun subaylarıyla erlerinin seçkin ve savaş değerlerinin pekiyi olduğunu vurgulamıştır. Sayısının 900 tüfek ve 6 makineli tüfek olduğunu 
söyleyerek bu kuvvetin en güçlü bir alaya denk geldiğine dikkat çekip, bu önemli anda bu güzide kuvvetin işe yarayacağını umduğunu belirtmiştir (Onar, 1995, C. 2, s. 249).

Mustafa Kemal Paşa, savaşın devam ettiği günlerde II. İnönü Zaferiyle ilgili olarak Meclis’te konuşmamış, konuyla ilgili açıklamaları Fevzi Paşa yapmıştır.

Mustafa Kemal Paşa, II. İnönü Zaferi üzerine Namık Kemal'in oğlu Ali Ekrem'in tebrik telgrafına 10 Nisan 1921 günü şu cevabı vermiştir: “Anadolu'nun ruhu, bütün feyz-i mukavemetini âbâ-i tarihinden ${ }^{65}$ almıştır. Bize bu mukaddes feyzi nefheden ${ }^{66}$ ervah- ${ }^{67}$ ecdad arasindan mükerrem ${ }^{68}$ babanızın pek büyük mevkii vardır. Mecruh vatanın halas-ü istiklâli için ölmek yolunda bugünkü nesle talim-i fedakârı eden büyük Kemal hakkında takrir$i^{69}$ tazimata $^{70}$ vesile olan telgrafnamenize arz-ı şükran-ı mahsûs ${ }^{71}$ eylerim efendim." (Atatürk'ün Tamim, Telgraf ve Beyannameleri 4, 2006, s. 392).

II. İnönü Zaferinin kazanılmasını müteakip Türk ordusu ile Yunan ordusu arasında 8-12 Nisan 1921 tarihlerinde Aslıhanlar Muharebesi, 13-15 Nisan 1921 tarihlerinde ise Dumlupınar Muharebesi yapılmıştır. Gerek Aslihanlar ve gerek Dumlupınar muharebeleri Yunan kuvvetlerinin Türk kuvvetlerini oyalaması şeklinde cereyan etmiş ve sonunda taktik üstünlüğü Yunanlılarda kalmıştır (Türk İstiklâl Harbi, 1966, s. 534, 574).

Mustafa Kemal Paşa o günlerde kendisine verilen bilgilere göre, Cenup Ordusu Kumandanı Refet Paşa’ya hitaben 12 Nisan 1921 tarihli bir telgraf göndermiş, II. İnönü Zaferi ve sonrasında Cephede gösterdiği yararlılıklardan bahsetmiş ve Dumlupınar Meydan Muharebesini kazandığı için onu kutlamıştır (Onar, 1995, C. 2, s. 255).

Mustafa Kemal Paşa 12-13 Nisan 1921 gecesi de Refet Paşa'ya şu telgrafı çekmiştir: “İnönü Meydan Muharebesinde silahlarımızın kazandığı parlak zaferi Dumlupınar Meydan Muharebesinde rüçhan-ı $\imath^{72}$ irade ve idarenizin temin ettiği ikinci ve parlak zafer itmam ${ }^{73}$ etti. Cinayet ve hiyanetinin ilk cezaların çekmeye başlayan Yunanistan'a karşı Anadolu'nun eski gaza ufukları üstünde ukab-ı zaferimiz ${ }^{74}$ ateşten iki kanat açtı. Ecdat topraklarında iki uzun seneden beri müfsit, muğfil ${ }^{75}$ bir mütareke ile silahlarından tecrit ${ }^{76}$ ve ölüme mahkûm edilmiş milletimiz aleyhine fasılasız bir yangin ve kital ${ }^{77}$ siyaseti takip eden, en mamur memleketlerimizi harabeye çeviren düşmanın başıboş bırakılmış haydut sürüleri yüzlerini döndürdüler. Ordumuz gök gürültülerini andıran pür velvele ve heybetle sahne-i tarihe yeniden çıtı. Başkalarının zaferinden doğmuş ve başkalarının zaferiyle büyümüş tufeyli ${ }^{78}$ düşmanı ana topraklarımızdan büsbütün tart edecek meșiyyet- $i^{79}$ muzafferanenizin yollarına gözlerim dikilmiş, size ve üstadane sevk ve idareniz altında ruh-u ecdadı mağrur eden bir kahramanlıkla çarpışan bütün kumandan ve silah arkadaşlarınıza mesut ve müftehir tebriklerimizi gönderiyorum." (Atatürk'ün Tamim, Telgraf ve Beyannameleri 4, 2006, s. 398).

\footnotetext{
${ }^{65}$ Âbâ: Ata, ecdat.

${ }^{66}$ Nefh: Yaymak, saçmak.

${ }^{67}$ Ervah: Ruhlar, canlar.

${ }^{68}$ Mükerrem: Hürmet ve tazim edilen.

${ }^{69}$ Takrir: İyi ifade etmek, bildirmek.

${ }^{70}$ Tazimat: Hürmet ve riayetler.

${ }^{71}$ Mahsûs: Belli, aşikâr, meydanda.

${ }^{72}$ Rüchan: Üstünlük, yükseklik.

${ }^{73}$ İtmam: Tamamlamak, bitirmek.

${ }^{74}$ Ukab: Kartal, sancak; ukâb: toz, duman.

${ }^{75}$ Muğfil: İğfal eden, aldatan.

${ }^{76}$ Tecrit: Yalnız başına bırakmak, ayırmak.

${ }^{77}$ Kital: Muharebe, kavga.

${ }^{78}$ Tufeyli: Davetsiz gelen, dalkavuk, asalak.

${ }^{79}$ Meşiyyet: İrade.
} 
Mustafa Kemal Paşa, Hopa'ya gelen Afgan sefirinin II. İnönü ve Dumlupınar zaferlerini tebrikine 12 Nisan 1921 tarihinde şöyle cevap vermiştir: "Memleketimize vusul ${ }^{80}$ ve teşrifinizi ve ordu-yu İslam tarafından düşmanlarımıza karşı ihraz edilen büyük muzafferiyetten mütevellit memnuniyet ve tebrikatınızı bize iblağ eden telgrafnamenizi aldık. Kahraman askerlerimizin zulüm ve melanet kuvveti olan Yunanlılara karşı kazandığı muvaffakiyet ne kadar mucib-i hazzımız olmuşsa din-i mübin-i İslam'ın en kavi bir rabıta-i uhuvvetle kendisine raptettiği Afganistan'ın selam ve muhabbetini bize getiren ve iki kardeş memleket arasında doğrudan doğruya tesis-i münasebet etmek imkân-1 mesudiyetini hâsıl eden heyet-i aliyenizi vatan toprağında kabul etmek o kadar mucib-i fahr-ü memnuniyetimiz olmuştur. Garp ve Cenup cepheleri kumandanları İsmet ve Refet Paşalara tebriklerini derhal tebliğ ettik. Cenab-1 Hakk'tan tazarru ve niyaz ederiz ki heyet-i aliyenizin memleketimize ayak basması ve iki dost ve kardeş memleketi yekdiğerini rabta vasıta olması memleketlerimizin istikbali için daimi bir sebeb-i hayır ve saadet olsun." (Atatürk'ün Tamim, Telgraf ve Beyannameleri 4, 2006, s. 396-397).

Mustafa Kemal Paşa, II. İnönü ve Dumlupınar zaferleri dolayısıyla İstanbul'dan Müşir Fuat ve Ferik Rıza Paşalar ve Sabık Âyan Reisi Rıfat Bey’in tebrik telgraflarına 16 Nisan 1921 günü şu cevabı vermiştir: "Hakk-1 hayatı nezedilmek ${ }^{81}$ istenilen milletimizin müdafaa ve istiklâl yolunda gösterdiği kahramanlıklar, pek çok mahafilden $^{82}$ tebrik edildi. Tebrikat-1 aliyelerini, elyevm ${ }^{83}$ ecnebi tazyiki altında bulunan payitahtımızdan yazılmış olmak itibariyle, bunlar meyanında en kıymetlilerinden addediyorum. Arz-1 teşekkürat eder ve azmi millinin timsal-i tuğyanı olan ordumuza nusret-i ilahiyenin aleddevam şamil olması hususunda dualarınızı rica eylerim efendim.” (Atatürk'ün Tamim, Telgraf ve Beyannameleri 4, 2006, s. 398-399).

Mustafa Kemal Paşa sonradan Batı Cephesindeki gelişmeleri incelediğinde Aslıhanlar ve Dumlupınar muharebelerinin kazanılmadığını görmüş ve gereken tedbirleri almıştır. Ancak daha sonra yaptığı bazı konuşmalarda Dumlupınar' da kazanılan başarılardan söz etmiştir.

Mustafa Kemal Paşa, Yunanlıların Anadolu'nun harim-i ismetinde boğulacağına dair ordu ve millete hitaben yayımladığ1 9 Ağustos 1921 tarihli beyannamede ise İnönü Savaşlarıyla ilgili olarak şunları söylemiştir: "Büyük muharebeden (I. Dünya Savaşı) çıktığımız en zaif zamanımızda tekmil memleketi çiğnemek ve bütün ahaliyi mahvetmek için üzerimize hücum eden düşmanlara karşı milletçe birleştik. Ve pek kıymetli ordular vücuda getirdik. Muhtelif ve müteaddit cephelerde emsalsiz fedakârlıklarla hukuk-u milleti müdafaa eden ve İnönü'nde Yunanistan'ın istila ordularını iki defa tepeleyen bu milli ordularımız o kadar yüksek bir azim ve iman ile muharebe ettiler ki düşmanlar yalnız Garp Cephemizdeki ordumuza karşı Kralları ${ }^{84}$ başta olduğu halde tekmil Yunan ordusunu Anadolu'ya getirmeye mecbur oldular. Garp Cephesinde vukua gelen son muharebatta bu düşman ordusunu pek mahuf ${ }^{85}$ zayiata duçar ettikten sonra ordumuzun cevher-i aslisinden hiçbir şey zayi etmeden bugünkü vaziyeti aldık. Bugün düşman ordusu menabi-i asliyesinden ve üss-ülharekesinden uzaklaşmış bir vaziyette karşımızdadır...” (Atatürk'ün Tamim, Telgraf ve Beyannameleri 4, 2006, s. 412-413).

Sakarya Meydan Muharebesinin kazanılması üzerine Mustafa Kemal Paşa, TBMM Reisi ve Başkumandan sıfatıyla 14 Eylül 1921'de Türk milletine hitaben yayımladığı ve 15 Eylül 1921'de Mecliste okunan beyannamede İnönü Savaşlarına değinerek şunları söylemiştir: “...İstanbul'da o zaman kendisine Türk

\footnotetext{
${ }^{80}$ Vusul: Ulaşma, erişme.

${ }^{81}$ Nez: yok etmek.

${ }^{82}$ Mahafil: Yer, yerler.

${ }^{83}$ Elyevm: Bugün, hâlâ.

${ }^{84}$ Bu kelime TITTE Arşivinde bulunan orijinal belgeden “kuralları” şeklinde hatalı okunmuştur (Atatürk'ün Tamim, Telgraf ve Beyannameleri IV, 2006,

${ }^{85}$ Mahuf: Korkulu, tehlikeli.
} s. 413). 
Hükümeti namını veren ve fakat ecnebilere hoş görünmek gayretiyle Türk milletinin en mukaddes menafiini ayaklar altına alan, vatan muhabbetinden mahrum birtakım ricalin caniyane müsamahasından bilistifade İzmir'e çıkan düşman bundan evvel dahi İnönü'nde ve Dumlupınar'da mükerreren Türk azim ve imanı karşısında mahkur ve mağlup edilmiş idi...” (TBMMZC, 15.9.1337, s. 216).

Mustafa Kemal Paşa, 19 Eylül 1921 günü Meclis’te umumi harekât-1 harbiye ve harici ahval hakkında bir beyanat vermiştir. Bu konuşmasında İnönü Zaferleriyle ilgili olarak şunları söylemiştir: “...Ordunun vücut bulmasını kendi menfaatlerine mugayir gören bazı hainler İstanbul ricalinin, İstanbul'un daima gafil ricalinin, tavır ve mişvarından ${ }^{86}$ da istifade ederek Hükümetinize isyan etti ve düşmanlara iltihak eyledi. Bunu pek müsait bir fırsat addeden düşmanlarımız derhal baskın tarzında Bursa'dan Eskişehir istikametinde taarruza geçtiler, öyle bir zamanda idi ki kuvvetlerimiz Gediz ve Simav cihetlerinde meşgul bulunuyorlardı. Fakat bu meşgul olan kuvvetlerimiz derhal İnönü’de topland. Düşman taarruz ve tecavüzünü emniyetle kabul etti ve ordumuz tarih-i millimize I. İnönü Zaferini kaydetti. Vaka İnönü'de bu zaferi ihraz etmiştik. Fakat arzu edilen orduyu vücuda getirmek için muhtaç olduğumuz zaman teehhür etmişti. Binaenaleyh artık bundan sonra yeniden ordumuzu teşkil ve taazzuv ${ }^{87}$ ettirebilmek için çalışmaya başlandı. Düşmanlarımız bu istihzarata ${ }^{88}$ da takaddüm ${ }^{89}$ etmek istediler. Bu defa daha çok kuvvetlerle ve daha büyük mikyasta, muhtelif istikametlerde yeni bir baskın hareketi icra eylemişlerdi. Bu baskın hareketi de yine ordumuz tarafından emniyetle karşılanmış ve neticesinde de II. İnönü Zaferini kazanmıştık. Tıpkı birincisi gibi bu ikinci zafer istihsal ${ }^{90}$ olunmakla beraber ordunun istihzaratı için yine teehhür vaki olmuştu. Binaenaleyh üçüncü defa yeniden pek büyük himmet ve gayretlerle ordunun istihzaratına devam edilmeye başlanıldı. Üzerimize saldıran Yunan kuvvetleri böyle Türk kuvvetlerine çarparak parçalandıkça, hakikaten bizi imha etmek isteyen düşmanlarımız daha büyük mikyasta tedbirler, teşvikler icra etmek ve hırslar uyandırmakla meşgul oldular ve bütün bu mesai neticesinde Yunanistan'ın hemen tekmil kuva-yı müsellahasından ${ }^{91}$ mürekkep fevkalade mükemmel, mücehhez, kuvvetli, büyük bir orduyu Anadolu'nun içerisine saldırttılar...” (TBMMZC, 19.9.1337, s. 255-256).

Mustafa Kemal Paşa 1 Mart 1922 günü Meclis’in üçüncü içtima senesinin açılışı nedeniyle yaptığı konuşmada Garp Cephesindeki gelişmelere değinirken de şunları söylemiştir: "Garp Cephesine gelince: Geçen sene bidayetinde ${ }^{92}$ I. İnönü Muharebesinden çıkmış bir vaziyette bulunan ordumuz mahiyeti düşmanlarımızca meçhul bir halde olarak, teşkilatını tevsi ve itmam eyliyordu. Bu esnada Yunanlılar Londra Konferansını zaman kazanacak ve Türkleri iğfal ${ }^{93}$ edecek bir vasıta telakki ederek, harekât mevsimini bekliyorlardı. Mart ortasında harekât mevsimi geldi ve Yunan ordusunun hazırlığı bitti. Artık zamana ihtiyaçları kalmamıştı. Müteazzımane $^{94}$ bir surette Londra Konferansını bertaraf ettiler. Martın yirmi üçünde her taraftan taarruza geçerek emperyalistlerin bir büyük müstemleke içindeki harekâtını taklit eder bir şekilde vatanımızı istilaya başladılar.

Tumturaklı ${ }^{95}$ işaat ${ }^{96}$ ile geçen ilk günlerden sonra çetin muharebelere girişildi. Binnetice tarihin II. İnönü Muharebesi dediği bir büyük hadise vukua geldi. Bu büyük hadiseyi Dumlupınar'daki harekât-1 taarruziye ve muvaffakiyetlerimiz takip eyledi.

\footnotetext{
${ }^{86}$ Mişvar: Tarz, tavır, gidişat.

${ }^{87}$ Taazzuv: Oluşturma, şekillendirme.

${ }^{88}$ İstihzarat: Hazırlıklar.

${ }^{89}$ Takaddüm: Önüne geçmek, engellemek.

${ }^{90}$ İstihsal: Kazanmak, elde etmek

${ }^{91}$ Kuva-yı müsellaha: Silahlı kuvvetler.

${ }^{92}$ Bidayet: Başlangıç.

${ }^{93}$ İğfal: Aldatmak, yanıltmak.

${ }^{94}$ Müteazzım: Büyüklük taslayan.

${ }^{95}$ Tumturaklı: Gösterişli, debdebeli.

${ }^{96}$ İşaat: Haber yaymalar.
} 
II. İnönü Muharebesi milletimizin davasındaki isabet ve kutsiyeti bütün dünyaya neşretti. Yunan müddeiyatındaki ${ }^{97}$ sahtelik de bütün cihanca malum oldu. Yine II. İnönü'nden sonra Yunanlılar memleketimizi yakmakla, silahsız ve silah kullanmaya kudretsiz evladımızı öldürmekle cibilliyetlerindeki vahşeti bütün dünyaya ispat eylediler. Bilecik, Bozüyük, Söğüt, Yenişehir yangınlarını ve saymakla bitmeyen ırz tecavüzatını ve katliamları Yunan kumandanlarının emriyle ve suret-i mahsusada teşkil olunan müfrezelerle yaptırdıkları, tahkikat neticesinde tezahür ve teeyyüd ${ }^{98}$ etmiştir.

Yunanlılar meselenin tahmin ettikleri kadar basit olmadığını II. İnönü Muharebesi'nde anladılar. Bunun üzerine umumi seferberlik suretinde esaslı bir surette tedabire tevessül eylediler. Bütün ordularıla ciddi bir sefere karar verdiler. Bir taraftan bu istihzarat devam ederken, diğer taraftan siyaseten bizi iğfale ve gevşekliğe sevk edecek siyasi propagandalar faaliyete getirildi. Yunan Kralı, Anadolu'ya geldi. Köyleri ihrak ${ }^{99}$ ve irza tecavüz etmek için emir veren generallerinin yakından kumandasını deruhte etti..." (TBMMZC, 1.3.1338, s. 13-14).

Mustafa Kemal Paşa, 1 Mart 1922'de Meclis'te yaptığı konuşmada da Dumlupınar'daki taarruz harekâtından ve muvaffakiyetten söz etmiştir.

Mustafa Kemal Paşa, II. İnönü Zaferinin yıl dönümü münasebetiyle 29 Mart 1922 tarihinde orduya hitaben şu beyannameyi yayımlamıştır: "338 (1922) Senesi Martının Otuzuncu günü II. İnönü Meydan Muharebesinin yıl dönümüdür. Zalim dünyaya karşı milletimizi baştanbaşa boğazlayabileceğini ilan ve taahhüt eden müstevli ve mağrur bir düşman geçen senenin 30 Mart günü yerlere serilerek hakkın galibiyetine boyun eğmişti. Tarihimizin en şerefli kahramanları meyanına giren II. İnönü şehitlerine fatihalar, gazilerine minnet ve şükranlar ithafına bütün cephedeki arkadaşlarımı davet ediyorum. Gasıp düşmanın zulüm ve itisafından ${ }^{100}$ inleyen vatanımıza ve milletimize karşı hakiki ve ciddi vazifelerimizi bütün arkadaşlarıma derhatır ettiririm. Her zamandan ziyade şuurlu ve kudretli olan kahraman ordularımızın az zamanda mübarek ve aziz vatan topraklarını düşmanın levsi ${ }^{101}$ vücudundan tahlise ${ }^{102}$ muvaffak olacakları ümniyyesiyle ${ }^{103}$ eltaf-1 ilahiyenin tecellisini tazarru eylerim." (Atatürk'ün Tamim, Telgraf ve Beyannameleri 4, 2006, s. 452).

Mustafa Kemal Paşa, II. İnönü Zaferinin yıl dönümü münasebetiyle Azerbaycan Şuralar Cumhuriyeti ve halkı namına tebriklerini bildiren İbrahim Abilov'a ${ }^{104} 31$ Mart 1922 tarihinde, Rusya Şuralar Cumhuriyeti ile halkı ve ordusu adına tebriklerini bildiren Aralov'a ${ }^{105}$ da 2 Nisan 1922'de cevap vermiştir. Her iki cevapta da II. İnönü muzafferiyetinin önemine dikkat çekmiştir. Bu önemli gelişmeden dolayı Azerbaycan ve Rusya’nın gösterdiği ilgiye teşekkür etmiştir. Türk ordusunun bu zaferin kazanılmasındaki etkisini vurgulamıştır. Azerbaycan ve Rusya’nın iyi niyetlerini belirten tebrikatın Türkiye Büyük Millet Meclisi’nde okunduğunu ve aynı zamanda orduya da bildirildiğini ve Türk ordusunun da Azerbaycan ve Rus ordularına selam ve ihtiramların $1^{106}$ sunduğunu ifade etmiştir (Atatürk'ün Tamim, Telgraf ve Beyannameleri 4, 2006, s. 453-454).

Mustafa Kemal Paşa II. İnönü Savaşıyla ilgili olarak Nutuk'ta da açıklamalar yapmıştır. Ona göre, Londra Konferansı çerçevesinde İtilaf Devletleri delege heyetimiz vasıtasıyla yaptıkları tekliflerin cevabını almayı beklemeden, daha delegelerimiz yolda iken, Yunanlılar bütün ordusuyla ve bütün cephelerimize karşı taarruza geçmiştir.

\footnotetext{
${ }^{97}$ Müddeiyat: İddialar.

98 Teeyyüd: Kuvvetlenme, onaylanma.

${ }^{99}$ İhrak: Ateşe atmak, yakmak.

${ }^{100}$ İtisaf: Zulüm ve haksızlık.

${ }^{101}$ Levs: Pislik, kir, zor, kuvvet, cerahat, yara.

102 Tahlis: Kurtarmak.

103 Ümniyye: Umut, arzu, talep.

104 İbrahim Abilov: Milli Mücadele yıllarında Ankara'da Azerbaycan Sovyet Sosyalist Cumhuriyeti'nin temsilcisi.

${ }^{105}$ Semyon İvanoviç Aralov: Milli Mücadele yıllarında Sovyetler Birliği'nin Ankara Büyükelçisi.

106 İhtiram: Hürmet, saygi.
} 
Yunan taarruzu konferans ve sulh hikâyesini zaruri olarak terk ettirmiştir. Yunan ordusunun Bursa ve doğusunda önemli bir grubu, Uşak ve doğusunda diğer bir grubu yer almıştır. Türk ordusu da Eskişehir'in kuzey-batısında, Dumlupınar'da ve doğusunda olmak üzere iki grup halinde konuşlanmıştır. Bundan başka Yunanlıların İzmit’teki tümenlerine karşılık Kocaeli Grubu kurulmuştur. Yunanlıların Menderes boyundaki birliklerine karşı da Türk birlikleri yer almıştır. Yunan ordusunun Bursa ve Uşak grupları, 23 Mart 1921 günü ileri harekâta geçmiştir. İsmet Paşa komutasında bulunan Batı Cephesi birlikleri, Eskişehir’in kuzey-batısında yığınak yapmıştır. Savaşı İnönü mevzilerinde kabul etme kararı alınmıştır. Ona göre hazırlıklar yapılmıştır. Düşman, 26 Mart akşamı, İsmet Paşa'nın işgal ettirdiği mevzilerin sağ kanadı ilerisine yanaşmıştır (Atatürk, 1994, s. 393). Ertesi günü bütün cephede karşılaşmalar olmuştur. Düşman 28 Mart günü Türk ordusunun sağ kanadına taarruza geçmiştir. 29 Martta da her iki kanattan taarruz etmiştir. Yunan ordusu yer yer önemli başarılar kazanmıştır. 30 Mart günü şiddetli savaşlarla geçmiştir. Bu savaşların da sonucu düşman lehine olmuştur (Atatürk, 1994, s. 394).

Bundan sonra sıra Türk ordusuna gelmiştir. İsmet Paşa 31 Mart günü, karşı taarruza geçmiş ve düşmanı yenerek, 31 Mart-1 Nisan gecesi geri çekilmeye mecbur etmiştir. Böylece, inkılap tarihimizin bir sayfası, II. İnönü Zaferiyle yazılmıştır.

Düşman çekilirken Batı Cephesi Komutanı İsmet Paşa, 1 Nisan günü Mustafa Kemal Paşa'ya Cephedeki son durumu şu sözlerle bildirmiştir:

\section{Metristepe, 1.4.1921}

Saat 18.30'da Metristepe'den gördü̈̆üm durum: Gündüzbey kuzeyinde sabahtan beri dayanan ve artçı olması muhtemel olan bir düşman müfrezesi, sağ kanat grubunun taarruzu ile düzensiz olarakçekiliyor. Yakından takip ediliyor. Hamidiye yönünde karşılaşma ve faaliyet yok. Bozüyük yanıyor. Düşman, binlerce ölüsüyle doldurduğu savaş meydanını silahlarımıza terk etmiştir.

Batı Cephesi Komutanı İsmet (Atatürk, 1994, s. 394)

Mustafa Kemal Paşa bu gelişme üzerine İsmet Paşa'ya hitaben içinde tarihe mal olmuş o meşhur cümlesinin de yer aldığı şu telgrafı göndermiştir:

\section{İnönü Savaş Meydanında Metristepe'de Batı Cephesi Komutanı ve Genelkurmay Başkanı İsmet Paşa'ya} Bütün dünya tarihinde, sizin İnönü Meydan Muharebelerinde üzerinize yüklendiğiniz görev kadar ağır bir görev yüklenmiş komutanlar pek azdır. Milletimizin istiklal ve varliğl, dâhice idareniz altında görevlerini şerefle yapan komuta ve silah arkadaşlarınızın kalbine ve vatanseverliğine büyük bir güvenle dayanıyordu. Siz orada yalnız düşmanı değil, milletin makûs ${ }^{107}$ talihini de yendiniz. İstila altındaki talihsiz topraklarımızla birlikte bütün vatan, bugün en ücra köşelerine kadar zaferinizi kutluyor. Düşmanın istila hırsı, azminizin ve vatanseverliğinizin yalçın kayalarına başını çarparak paramparça oldu.

Adınızı tarihin şeref abidelerine yazan ve bütün millete size karşı sonsuz bir minnet ve şükran duygusu uyandiran büyük gaza ve zaferinizi tebrik ederken, üstünde durduğunuz tepenin size binlerce düşman ölüleriyle dolu bir şeref meydan seyrettirdiği kadar, milletimiz ve kendiniz için yükseliş parıltılarıyla dolu bir geleceğin ufkuna da baktığını ve hâkim olduğunu söylemek isterim.

Büyük Millet Meclisi Başkanı

Mustafa Kemal (Atatürk, 1994, s. 394)

\footnotetext{
${ }^{107}$ Makûs: Tersine dönmüş, uğursuz.
} 
İsmet Paşa da Mustafa kemal Paşa'ya şöyle cevap vermiştir:

Büyük Millet Meclisi Başkanı Mustafa Kemal Paşa Hazretleri'ne

Zulüm ve zorbalık dünyasının en zalimce hücumlarına karşı yalnız ve şaşkın kalan milletimizin maddi ve manevi bütün kabiliyet ve kuvvetlerini ruhundaki ateşle toplayan ve harekete getiren Büyük Millet Meclisi'nin Başkanı Mustafa Kemal Paşa!

Kahraman askerlerimiz ve subaylarımız adına, askerlerimizle avcı hatlarında omuz omuza vuruşan tümen ve kolordu komutanları adına takdir ve tebriklerinize büyük bir iftiharla teşekkürlerimi arz ederim.

Batı Cephesi Komutanı

İsmet (Atatürk, 1994, s. 395).

Mustafa Kemal Paşa, II. İnönü Zaferinden hemen sonraki gelişmelerle ilgili olarak da Nutuk'ta şunları söylemiştir:

"Yunan ordusunun Uşak grubunun Dumlupınar'dan sonra, Eskişehir'e doğru yürümesi gerekirken Afyon üzerinden Konya’ya doğru yönelmesi, kuvvetlerini asıl kesin sonuç alacağı alandan uzaklaştırarak, işe yaramaz ve tehlikeli bir durumda bırakmıştır. İnönü'deki başarı bizim tarafta kaldıktan sonra, bu kuvvetlerin, kendilerini tehlikeden kurtarmak için biran önce süratle geri çekilmelerini sağlamaktan başka bir şey düşünmeyeceklerine şüphe kalmamıştır. İnönü’de zafer kazanan kuvvetlerimiz, Eskişehir, Altıntaş üzerinden Dumlupınar'a yönelerek bu mesafenin önemli bir kısmında demiryolundan fazlasıyla yararlanma imkânı bulunduğuna göre, Afyonkarahisar'ın doğusunda bulunan Yunan grubu geri çekilme hattını kesebilir ve böylece, pek büyük bir ihtimalle o grubu büyük bir felakete uğratabilirdi. Nitekim bu düşüncenin uygulanmasına geçmekte biran gecikilmemiştir. İlk serbest kalan tümenler derhal Güney Cephesi Komutanı Refet Paşa'nın emrine verilerek harekete geçirilmiştir (Atatürk, 1994, s. 395).

İnönü Meydan Muharebesi'nden alınan sonuç üzerine, Yunan ordusunun Uşak grubunun derhal geri çekilmeye başladığını ifade eden Mustafa Kemal Paşa, sonraki süreçte Refet Paşa'nın taktik ve stratejik hatalar yaptığından dolayı onun komutası altında bulunan Güney Cephesi'ni, Batı Cephesi'ne bağlayarak İsmet Paşa'nın komutasına vermiştir. Refet Paşa'ya Milli Müdafaa Vekili olmasını önermiş o da Genelkurmay Başkanı olmak istediğini söyleyince bu isteği kabul edilmemiştir. Refet Paşa da bakanlığı kabul etmemiş ve Kastamonu'da bir süre dinlenmeye çekilmiştir (Atatürk, 1994, s. 396-398).

Mustafa Kemal Paşa'nın Nutuk'taki açıklamalarından anlaşılacağı üzere Dumlupınar Zaferi konusunda yaşanan tereddüdün sebebi şudur: Afyon'un doğusunda bulunan düşman tümenlerinin Dumlupınar'in ilerisinde bıraktıkları bir alaylarının yenilip saf dışı edilememesi yüzünden, düşman kuvvetleri Dumlupınar’a kadar çekilme imkânını bulabilmiştir. Bundan sonra, Yunan kuvvetlerinin, sağlam bir muharebe hattı tutmak üzere tertibat alırken, ilerideki birliklerinin o hatta ulaşmak üzere geri yürüyüşleri, Refet Paşa'nın muharebesinin sonucu hakkında yanlış bir yargıda bulunmasına yol açmıştır. Refet Paşa, kendisi yenildiği halde, düşmanın yenilip geri çekildiğini sanmış ve bunu, beş gün süren Dumlupınar Meydan Muharebesi'nde, düşmana son darbenin vurulabildiğini bildiren telgrafıyla Mustafa Kemal Paşa'ya da haber vermiştir. Mustafa Kemal Paşa da pek tabii memnun olarak büyük takdir ve tebriklerde bulunmuştur. Fakat durumu iyice anlamak için telgraf başında kendisine sorduğu sorulara aldığ cevaplardan, durumun bildirildiği gibi olmadığı şüphesine düşmüştür. Durum sakinleşmeye başladıktan sonra Refet Paşa'nın komuta ettiği orduda, kendisine karşı güvenin kalmadığı anlaşılmış ve görev değişikliği yoluna gidilmiştir (Atatürk, 1994, s. 397).

Mustafa Kemal Paşa'nın Nutuk'taki ifadelerinden Dumlupınar'daki yanlış anlamanın o günlerde telgraf başında Refet Paşa'nın kendisine verdiği cevaplardan anlaşıldığı ifade edilmiş ancak Mustafa Kemal Paşa’nın olaydan bir iki yıl sonra da bazı yerlerde Dumlupınar başarısından bahsettiği görülmüştür. Dolayısıyla burada bir çelişki olduğu dikkat çekmektedir. 
Mustafa Kemal Paşa Nutuk’ta II. İnönü Muharebesiyle ilgili son olarak şunları söylemiştir: “Saygıdeğer Efendiler, olayları Sakarya Meydan Muharebesi'ne getirmek istiyorum. Fakat bunun için müsaade buyurursanız, ufak bir giriş yapacağım. II. İnönü Muharebesi'nden sonra, üç ay kadar bir zaman geçti. Ondan sonra 10 Temmuz 1921 tarihinde, Yunan ordusu yeniden cephemize genel taarruza girişti (Atatürk, 1994, s. 412).

Mustafa Kemal Paşa, 1934 yılında Soyadı Kanunu çıkınca, inkılap tarihinin ilk şerefli ve parlak sahifesi olarak gördügü İnönü meydan muharebelerinin başkahramanı olması itibariyle İsmet Paşa'nın aile isminin İnönü olmasını çok yerinde bulmuş ve kendilerine bu soyadını vermiştir (Atatürk'ün Tamim, Telgraf ve Beyannameleri 4, 2006, s. 640).

\section{Sonuç}

Mustafa Kemal Paşa'ya göre Ethem ve kardeşlerinin isyan ederek Yunan tarafında yer almaları, İngilizler ve Yunanlılara verdikleri malumat Batı Cephesinde Yunan ordusunun yeniden saldırıya geçirilmesine ve I. İnönü Savaşına vesile olmuştur. Ethem ve kendisine bağlı kuvvetlerin tavrı I. İnönü Muharebesinde düşmana avantaj sağlamış ancak nihai zaferin kazanılmasını önleyememiştir. Ethem ve kuvvetleri yenilerek Yunanlılara sığınmıştır. Mustafa Kemal Paşa'nın 8 Ocak 1921'de Meclis'e verdiği izahat sonunda Ethem'in ağabeyi Reşit Bey’in mebusluğu düşürülmüştür. Ethem ve kuvvetlerinin etkisiz kılınmasıyla birlikte Batı Cephesinde yapılan şiddetli muharebeler sonunda Yunan ordusu da yenilerek geri çekilmek zorunda kalmıştır.

Bir maymun tarafından ısırıldıktan sonra hayatını kaybeden Yunan Kralı Aleksander'ın yerine geçen Kral Konstantin, İngilizlerin emperyalist emellerine alet edilmiştir. Krallığını kabul ettirebilmek için İngilizlerin istediği gibi hareket etmek zorunda kalan Konstantin, Ethem ve kardeşlerinin desteğini almak istemiştir. Ethem ve kardeşleri I. İnönü Savaşında izledikleri yolla hem İngiliz hem de Yunan emellerinin gerçekleşmesine hizmet etmişlerdir. Onların Türk ordusu, Türk halkı ve TBMM hakkında yaptıkları asılsız propagandadan bir sonuç çıkmamıştır.

Mustafa Kemal Paşa, I. İnönü Zaferini mukaddes vatan topraklarını düşman istilasından tamamen kurtaracak kesin zaferin hayırlı bir başlangıcı olarak görmüştür.

Meclis'in dik duruşu orduyu ve halkı daha da cesaretlendirmiştir. I. İnönü Muharebesi TBMM'nin göstermiş olduğu azim, irade, soğukkanlılık ve dirayetle kazanılmıştır.

Mustafa Kemal Paşa, I. İnönü Zaferinin kazanılmasından aldığı moral ve güvenle Namık Kemal'in meşhur şiirine atıfta bulunarak şu unutulmaz sözleri söylemiştir:

\section{Vatanın bağrına düşman dayasın hançerini}

Bulunur kurtaracak bahtı kara maderini.

Mustafa Kemal Paşa'ya göre, I. İnönü Muharebesi sonunda Türk ordusunun Yunan ordusunu takip edecek hatta Bursa'ya girecek gücü mevcuttur. Ancak bazı sebeplerden dolayı buna karar vermedikleri için ordu durdurulmuştur.

Mustafa Kemal Paşa, I. İnönü Zaferini Doğu Cephesinde Ermenilere karşı kazanılan zaferle eş değerde görmüş dolayısıyla Şarkta Ermenilerin Garpta da Yunanlıların mağlup edildiğine dikkat çekmiştir.

Yunan ordusu ve kendisiyle iş birliği yapan yerli asiler yeni Türkiye Devletinin kuruluşuna ve Millet Meclisi'nin varlığına ve meşruiyetine saldırmıştır. Yaşama hakkı ve bağımsızlık gayesiyle mücadele eden Türk ordusu ise kendinden üç misli fazla olan düşmanı I. İnönü Meydan Muharebesinde mağlup etmiş ve harp 
tarihine güzel bir örnek yazdırmıştır. Türk milleti istiklaline ne kadar düşkün olduğunu bu muharebeyle dünyaya ispat etmiştir.

Refet Paşa, I. İnönü Muharebesi sırasında kendinden beklenen performansı gösterememiş, doğru ve isabetli kararlar alamamıştır. Buna rağmen Yunan ordusu İnönü'de üç günde mağlup edilmiştir. Bu zaferle Büyük Millet Meclisi'nin rahatlayacağı ve memnun olacağı yeni bir devir açılmıştır.

Mustafa Kemal Paşa I. İnönü Muharebesinin aksine II. İnönü Muharebesi sırasında ve sonrasında Meclis'te konuşma yapmamıştır. Meclis’i bu konuda Fevzi Paşa bilgilendirmiştir.

Mustafa Kemal Paşa'ya göre, II. İnönü Zaferinin kazanılmasında Namık Kemal'in de rolü vardır. Yaralı vatanın bağımsızlığını korumak için bugünkü nesle hayatını ortaya koyma talim ve terbiyesini verenlerden biri de odur. Mustafa Kemal Paşa, onu bu vesileyle “Büyük Kemal” olarak nitelendirmiştir.

II. İnönü Zaferi kazanıldıktan sonra kaçan düşman takip edilirken Aslıhanlar ve Dumlupınar muharebeleri yapılmış ancak bu muharebelerde Yunan ordusuna karşı belirgin bir üstünlük sağlanamamıştır. Buna rağmen Refet Paşa o günlerde Cepheden verdiği raporlarda düşmanın yenilgiye uğratıldığını bildirmiş, Mustafa Kemal Paşa da kendisini telgrafla tebrik etmiştir. Bu durum iç ve dış politikayla ilgili bazı belgelere de yansımıştır. II. İnönü Zaferiyle birlikte Dumlupınar Zaferinden de bahsedilmiştir. Sonradan durumun söylenildiği gibi olmadığını anlayan Mustafa Kemal Paşa gerekli tedbirleri alarak Refet Paşa'nın görevini değiştirmek istemiş bunu kabul etmeyen Refet Paşa, Cephedeki görevinden ayrılmıştır. Buna rağmen Mustafa Kemal Paşa, 14 Eylül 1921 tarihli beyannamede ve 1 Mart 1922'de Meclis'in üçüncü toplantı yllı açılışında yaptığı konuşmada II. İnönü Zaferinin yanı sıra Dumlupınar'daki taarruz ve muvaffakiyetlerden bahsetmiş, Nutuk'ta ise Refet Paşa’nın yenildiği halde bunu anlayamadığını ve düşmanın yenildiğini sandığını söylemiştir.

Mustafa Kemal Paşa'ya göre Kralları başlarında olmak üzere bütünüyle Anadolu’ya giren Yunan ordusu ana kaynaklarından ve hareket üssünden çok uzaklaştığı için I. ve II. İnönü Muharebelerinde başarılı olamamış ve Türk ordusuna önemli bir zayiat verdirememiştir. Yunan ordusu I. İnönü Muharebesinde ve II. İnönü Muharebesinde Türk ordusuna çarptıkça parçalanmıştır.

I. İnönü Muharebesinden zaferle çıkan Türk ordusu teşkilatını tamamlamaya çalışırken, Yunanlılar, Londra Konferansını zaman kazanacak ve Türkleri aldatıp, yanıltacak bir vasıta olarak görüp, harekât mevsimini beklemiştir. Mart ayında harekât zamanı gelince Londra Konferansını bertaraf ederek Anadolu'yu yeniden istilaya başlamıştır. Bu istila hareketi II. İnönü Zaferiyle durdurulmuştur. Bu zafer, Türk milletinin davasındaki haklılık ve kutsallığı tüm dünyaya göstermiştir. Yunan iddialarının asılsız olduğu da anlaşılmıştır. Anadolu'daki Yunan zulmü de delilleriyle ortaya koyulmuştur. Yunanlılar Anadolu’yu istila girişiminin zannettikleri kadar kolay olmadığını II. İnönü Muharebesinde anlamıştır. Dolayısıyla siyasi propaganda ve askeri faaliyetlerini daha da artırmak zorunda kalmıştır.

Mustafa Kemal Paşa'ya göre, dünyaya karşı Türk milletini yok edeceğini ilan ve taahhüt eden istilacı ve gururlu bir düşman II. İnönü Zaferiyle yerlere serilerek hakkın galibiyetine boyun eğmiştir. Türk inkılap tarihinin önemli bir sayfası II. İnönü Zaferiyle yazılmıştır. Mustafa Kemal Paşa, "Siz orada yalnız düşmanı değil, milletin makûs talihini de yendiniz” sözüyle zaferden duyduğu memnuniyeti belirtmiştir.

İnönü Zaferleri Millî Mücadele içinde önemli bir yer tutmuş, Türk milletine ve ordusuna cesaret ve güven kazandırmıştır. Lozan’a giden yolda kilometre taşlarından biri olmuştur. 


\section{Kaynakça}

Apak, R. (1990). İstiklâl savaşında garp cephesi nasıl kuruldu. Ankara: Türk Tarih Kurumu Basımevi.

Atatürk, M. K. (1994). Nutuk 1919-1927. (Yay. haz.: Zeynep Korkmaz), Ankara: Atatürk Araştırma Merkezi Yayınları.

Atatürk'ün söylev ve demeçleri 1-3. (2006). (Açıklamalı Dizin ile), Ankara: Atatürk Araştırma Merkezi Yayınları.

Atatürk'ün tamim, telgraf ve beyannameleri 4. (2006). (Açıklamalı Dizin ile), Ankara: Atatürk Araştırma Merkezi Yayınları.

İnönü, İ. (1985). Hatıralar. (Yay. haz.: Sabahattin Selek), İstanbul: Bilgi Yayınevi.

Onar, M. (1995). Atatürk'ün kurtuluş savaşı yazışmaları 1-2, Ankara: T.C. Kültür Bakanlığı Yayınları.

Tansel, S. (1991). Mondros'tan mudanya'ya kadar, Cilt IV, İstanbul: Milli Eğitim Basımevi.

TBMMZC, 8.1.1337/1921, Devre: 1, İçtima Senesi: 1, İ. 131, C. 2.

TBMMZC, 10.1.1337/1921, Devre: 1, İçtima Senesi: 1, İ. 132, C. 1.

TBMMZC, 13.1.1337/1921, Devre: 1, İçtima Senesi: 1, İ. 133, C. 1.

TBMMZC, 13.1.1337/1921, Devre: 1, İçtima Senesi: 1, İ. 133, C. 2.

TBMMZC, 1.3.13371921, Devre: 1, İçtima Senesi: 2, İ. 1, C. 1.

TBMMZC, 1.3.1337/1921, Devre: 1, İçtima Senesi: 2, İ. 1, C. 2.

TBMMZC, 24.3.1337/1921, Devre: 1, İçtima Senesi: 2, İ. 11, C. 2.

TBMMZC, 2.4.1337/1921, Devre: 1, İçtima Senesi: 2, İ. 15, C. 2.

TBMMZC, 4.4.1337/1921, Devre: 1, İçtima Senesi: 2, İ. 16, C. 2.

TBMMZC, 13.4.1337/1921, Devre: 1, İçtima Senesi: 2, İ. 20, C. 2.

TBMMZC, 15.9.1337/1921, Devre: 1, İçtima Senesi: 2, İ. 76, C. 1.

TBMMZC, 19.9.1337/1921, Devre: 1, İçtima Senesi: 2, İ. 79, C. 1.

TBMMZC, 1.3.1338/1922, Devre: 1, İçtima Senesi: 3, İ. 1, C. 1.

Türk istiklâl harbi. (1966). Cilt 2, Kısım 3, Ankara: Genelkurmay Basımevi.

\section{Extended Abstract}

\section{Purpose}

Mustafa Kemal Pasha went to Samsun on May 19, 1919. On this date, he started the National Struggle. One of the fronts where the National Struggle took place is the Western Front. The Western Front has a special importance for Mustafa Kemal Pasha. Mustafa Kemal Pasha assigned Ali Fuat Pasha to the Command of the Western Front with the decision taken by the Sivas Congress. Later, he sent Ali Fuat Pasha to Moscow as an ambassador. He divided the Western Front into two. He assigned Colonel İsmet Bey to the western part and Colonel Refet Bey to the southern part. Mustafa Kemal Pasha established the regular army on the Western Front. This regular army established by Mustafa Kemal Pasha defeated the Greek army many times on the Western Front. On these fronts' victories won against the Greek army has contributed to the establishment of the Republic of Turkey. The Battles of İnönü were also among these victories. The ideas of the republic's 
founder Mustafa Kemal Pasha, were influential in the establishment of the Republic of Turkey and it is of great importance for the Battles of İnönü. The purpose of this study is to reveal how Mustafa Kemal Pasha evaluated these battles and his views on these battles.

\section{Design and Methodology}

In order to achieve this goal, the attitude of Mustafa Kemal Pasha during the Battles of İnönü was investigated. The recommendations of Mustafa Kemal Pasha on the measures to be taken against Circassian Ethem and his forces before the First Battle of İnönü were determined. How he directed the Western Front commanders, İsmet Bey and Refet Bey was examined. It was examined how Mustafa Kemal Pasha provided communication between the Parliament and the army during the Battles of İnönü. It was examined how Mustafa Kemal Pasha informed Turkey Grand National Assembly about the Battles of İnönü. The thoughts of Mustafa Kemal Pasha on the Çerkez Ethem rebellion, the First Battle of İnönü, the London Conference and the Second Battle of İnönü were investigated. The speeches and words of Mustafa Kemal Pasha about the Battles of İnönü were compiled. Grand National Assembly of Turkey in this era of war and Turkey Grand National Assembly official reports and confidential official reports were examined. All the speeches and words that Mustafa Kemal Pasha made in the Assembly regarding this issue have been determined. How it is reflected in this subject matter to the Grand National Assembly of Turkey, where, how and what kind of calls are made in these negotiations and Mustafa Kemal Pasha's words have been determined. The speeches and statements made by Mustafa Kemal Pasha on this subject outside the Assembly, and the circular he published and the telegrams he sent were examined. The correspondence of Mustafa Kemal Pasha during the War of Independence was also handled in this respect. The words of Mustafa Kemal Pasha in his speech about the Battles of İnönü were also identified. After these determinations are made, Mustafa Kemal Pasha's words about the Battles of İnönü were listed in chronological order. In addition, the words of Mustafa Kemal Pasha were analyzed. Thus, his attitude and ideas during the Battles of İnönü were determined.

\section{Findings}

At the end of this study, the following findings were reached: Mustafa Kemal Pasha followed the activities of Çerkez Ethem before the Battles of İnönü and warned the commanders of the Western Front. Atatürk wanted Çerkez Ethem to surrender. When this was not accepted, he suggested that the rebellion of Çerkez Ethem should be suppressed by force. Çerkez Ethem gave information about the Turkish army to the military units of Greeks and British. Çerkez Ethem rebellion caused the Greek army to attack. Mustafa Kemal Pasha was convinced the deputies with his speech at the Turkish Grand National Assembly. At the end of this speech, Çerkez Ethem's brother Reşit Bey's deputy was dropped. Mustafa Kemal Pasha informed the Assembly about the First Battle of İnönü. He made statements about the war. According to Mustafa Kemal Pasha, the British incited on the Greek army in Turkey. The Greek army wanted to invade Eskişehir. Çerkez Ethem has also acted to achieve this. He helped the Greek army. First the forces of Çerkez Ethem and then the Greek army were defeated. While the Greek army retreated, it harmed the civilian population. After winning the First Battle of İnönü, Mustafa Kemal Pasha has congratulated the Western Front Commander İsmet Bey on behalf of the Grand National Assembly of Turkey.

The deputies in the parliament bravely supported the army. Their composure was instrumental in achieving victory. Mustafa Kemal Pasha reminded Namık Kemal's homeland poetry during the meeting in the Parliament regarding the First Battle of İnönü. He said that the salvation of the homeland will definitely come true. He stated that after the First Battle of İnönü, the Turkish army had the power to enter Bursa. He stated that they did not decide this. While the Armenian army was defeated in the east, the Greek army was defeated in the First Battle of İnönü in the west. Greek army was more powerful than Turkish Army. The First Battle of Inönü was a shining example of the history of war. This battle has proven that the homeland will be saved. The 
Greek army was defeated in İnönü in three days. The Grand National Assembly was relieved and a new era was opened. The Greek army used the London Conference to save time. Meanwhile, he has completed his preparations. When the time of operation came, he attacked again.

Before the Second Battle of İnönü, the National Assembly Guard Battalion was sent to the front. Mustafa Kemal Pasha commemorated the Homeland Poet Namık Kemal once again due to the Victory at the Second Battle of İnönü and praised him. After the Second Battle of İnönü, the Battles of Aslihanlar and Dumlupınar were fought, but the Greek army was not completely defeated. According to Mustafa Kemal Pasha, Refet Pasha, who failed to show the expected success in the First Battle of Inönü, showed himself as successful despite his failure in the follow-up operation after the Second Battle of İnönü. Mustafa Kemal Pasha congratulated him. It was understood that Refet Pasha was unsuccessfull. Mustafa Kemal Pasha wanted to change his deputy. But Refet Pasha didn't accept. He went to Kastamonu by his own wish. Mustafa Kemal Pasha united the Western Front and appointed İsmet Pasha as its commander. According to Mustafa Kemal Pasha, Refet Pasha was defeated but could not understand that he was defeated. This situation of Refet Pasha has become an important problem. Despite Refet Pasha's failure, the Greek army could not achieve its goals. It could not cause a significant casualty to the Turkish army. The Greek army crashed into the Turkish army during the Battles of İnönü and was torn. İsmet Pasha played an active role in winning these battles. The misfortune of the Turkish nation has also been defeated here.

\section{Implications (Theoretical, Practical and Social)}

The difference of opinion between Mustafa Kemal Pasha and Refet Pasha over the Battles of İnönü is quite interesting. We have the congratulatory telegram Mustafa Kemal Pasha sent to Refet Pasha. In addition, in his speeches long after the Battles of İnönü, he mentioned the success achieved in the Battles of Dumlupinar and Aslihanlar. Despite, he expressed the failure of Refet Pasha in Speech. Therefore, the reasons why Mustafa Kemal Pasha congratulated Refet Pasha first and then criticized him is an issue that needs to be investigated separately.

\section{Research Limitations}

In this study, the words of Mustafa Kemal Pasha about the Battles of İnönü were examined and his ideas were revealed.

\section{Originality/Value}

The absence of a similar study on this subject before has made this study unique. The fact that Mustafa Kemal Pasha is the most effective and authoritative person in this regard has further increased the value of the work. Readers were provided with the opportunity to listen and see the Battles of İnönü firsthand. The influence of Mustafa Kemal Pasha on winning these wars was also revealed. The importance of the Battles of İnönü has also been understood.

Araştırmacı Katkısı: Alaattin UCA (\%100). 